\title{
Bloot 'n vrees vir verval? 'n Mentaliteitsgeskiedenis van die kragonder- brekings in Suid-Afrika, Januarie-April 2008
}

JWN Tempelhoff*

Opsomming: Aan die begin van 2008 was groot dele van Suid-Afrika geraak deur kragonderbrekings wat sporadies en oor 'n groot gebied vir 115 dae an die orde was nadat die nasionale kragvoorsieningsinstansie, ESKOM, gebuk gegaan het onder wat, volgens die media, aan ongeëwenaarde kragverbruik toegeskryf is.

Die respons van verbruikers in alle samelewingsfere het gewissel van woede-uitbarstings tot ' $\mathrm{n}$ gelate aanvaarding van die toestand. Beskou vanuit die perspektief van die geskiedenis van mentaliteite, was die respons simptomaties van 'n kulturele reaksie wat daarop gedui het dat gewone mense van mening was dat 'n infrastrukturele diens, soos kragvoorsiening, mos nie net tot stilstand kan kom nie.

In die studie word gelet op die wyse waarop die kragonderbrekings van Januarie-April 2008 gekaats kan word teen die agtergrond van 'n andersoortige ervaring van herinneringe wat, nie net in Suid-Afrika nie, maar ook in ander wêrelddele, manifesteer. In wese kom dit daarop neer dat daar sprake is van 'n mentaliteitsgeskiedenis wat in die hede vasgevang is.

Trefwoorde: Elektrisiteit, Eskom, Kragonderbrekings, Dienslewering.

Dissiplines: Geskiedenis, Tegnologiestudies, Openbare Bestuur, Kommunikasiekunde.

\section{Inleiding: Vrees as drywer teen verval}

Verval, verklaar Jared Diamond, is die resultaat van wilsbesluite wat deur ' $n$ samelewing geneem word. ${ }^{1}$ Aan die hand van 'n reeks historiese en kontemporêre gevallestudies uit verskillende wêrelddele, maak hy in een van sy resente werke 'n sterk saak uit vir dié standpunt. Hy verduidelik dat die historiese rekord daarop dui dat optredes wat tot verval aanleiding gegee het die resultaat was van 'n onvermoë

* Navorsingsnisarea vir die Kulturele Dinamika van Water (CuDyWat) Noordwes-Universiteit, Vanderbijlpark. E-pos: johann.tempelhoff@nwu.ac.za. Gebaseer op 'n voordrag gelewer by die jaarlikse kongres van die Suid-Afrikaanse Vereniging vir Kultuurgeskiedenis, “Die toekoms van ons verlede”, Pretoria, 16 Mei 2008. 
om dinge te antisipeer. Samelewings het in meeste gevalle bloot slegte besluitnemingsprosesse gevolg. Nog meer, rampspoedige waardestelsels het in baie opsigte daartoe aanleiding gegee dat die soeke na oplossings op mislukkings uitgeloop het. Die lees van Diamond se werk sal vir menige, veral siniese Suid-Afrikaner, 'n gevoel van déjà vu gee. Benewens 'n fase van stagnasie in die land se ekonomie en onstabiliteit in die leierskapsgeledere van die regerende ANC-alliansie, het Suid-Afrika aan die begin van 2008 'n voorheen ongekende reeks elektriese kragonderbrekings deurgemaak, soveel so dat daar in die samelewing 'n wesentlike vrees ontstaan het dat die land immanente verval in die gesig staar. Vir doemprofete was die tydperk sprekend van 'n afwaartse spiraal waarin die land verkeer. ${ }^{2}$ Daar was mense soos byvoorbeeld 'n briefskrywer aan 'n koerant wat gemeen het dat die land se naam na Matlakala ('Gemors') verander word. ${ }^{3}$ Ander het weer geredeneer dat dit eintlik die resultaat was van 'n positiewe ontwikkelingsproses. ${ }^{4}$ Dié mense het gemeen die toedrag van sake beteken eintlik dat die land besig is om uit sy nate te bars. Vir die doeleindes van hierdie bespreking gaan dit nie noodwendig oor watter siening van die land korrek was nie. Veel eerder gaan dit oor hoe Suid-Afrikaners in die hoofstroom van dinge oor die kragonderbrekings gevoel het. Ook word van die standpunt uitgegaan dat dit moontlik is om vanuit 'n kultuurhistoriese perspektief van die krisis kennis te neem en om dan, aan die hand van hedehistoriese metodologiese grondslae, 'ninsig probeer kry vir'n kontemporêre samelewingsprobleem wat hom waarskynlik in die toekoms gaan herhaal. Die doelwit is om te verstaan wat die mentaliteit van die samelewing was in 'n tyd van krisis - 115 dae van landwye kragonderbrekings tussen 18 Januarie en 30 April 2008. Dit vereis dat strategieë wat historici tradisioneel benut om die menslike toestand in die verlede te verken, nou aangewend word om die hede te verstaan. ${ }^{5}$ In die besonder gaan dit oor die verkenning van die menslike natuur op 'n bepaalde tydstip en die bepaling van watter onderliggende geestesstrominge daartoe meegewerk om die denke van mense te beïnvloed. Dit gaan dus oor die funksionele benutting van aspekte van die kultuur- en tegnologiegeskiedenis.

\section{Metodologiese vertrekpunte: mentaliteite, herinnering, hedegeskiedenis en infrastruktuur}

In hierdie bespreking word op drie onderafdelings van kultuurgeskiedenis gekonsentreer, te wete mentaliteite, herinnering en hedegeskiedenis. Die geskiedenis van mentaliteite is 'n benadering tot wetenskaplike geskiedsbeoefening wat in die twintigte eeu omvattend deur die Franse Annaleskool verken is en veral op die terrein van de Franse kultuurgeskiedenis 'n bepaalde invloed uitgeoefen het. ${ }^{6}$ Vandag, word aanvaar, hou mentaliteite verband met die ervaring van herinnering en die werklikheidsbegrip wat by die gewone mens op enige gegewe tydstip aanwesig mag wees. Om die mentaliteit van 'n era te verstaan, beteken dat die ideëwêreld van die alledaagse gedefinieer word om tot beter insigte te kom oor waarom mense op 'n bepaalde manier handel. Førland reken dit is ook 'n kartering van Zeitgeist - opsigself 'n weerspieëling van die kultuurklimaat van 'n era, wat as 'n sosiale wordende toestand aangewese is op 'n

2. Vir 'n besonder intensiewe reeks perspektiewe oor Suid-Afrika na aanleiding van die elektrisiteitskrisis, kyk Solidariteit, Eskomstories by http://www.eskomstories.co.za/argief.htm (Geraadpleeg Maart-Mei 2008).

3. K Boshoff, Bloemfontein - Redakteur, "Verander SA se naam" in Volksblad, 2008.02.07 by http://www. news24.com/Die_Volksblad/Briewe/0,5-89_2266700,00.html (Geraadpleeg 2008.05.08).

4. Anon., "Lex column: South Africa power cuts" in Financial Times, 2008.01.29 by http://search.ft.com/f tArticle?query Text $=$ electricity + and + south + africa\&aje $=$ true\&id $=080129000239 \& c t=0 \&$ nclick_check $=1$ (Geraadpleeg 2008.05.05).

5. Die grootste gedeelte van hierdie teks is ten tyde van die kragonderbrekings geskryf.

6. P Hutton, "The history of mentalities: the new map of cultural history" in History \& Theory, 20(3), December 1981, pp. 237-259 
magdom gedagtes wat in 'n verskeidenheid van vorme in 'n samelewing uitkristalliseer.'

Metodologies vorm herinnering onderdeel van beide mentaliteit en hedegeskiedenis. As gevolg van die ontginning van nuwe media van kommunikasie het herinnering as sleutelkomponent vir die verstaan van die verlede die tradisionele konsep van historiese bewussyn begrens en onder sommige omstandighede vervang. Metodologies word herinnering beskou as 'n strategie om te herinner, herhaal en sodoende 'n kognitiewe raamwerk daar te stel om te interpreteer wat deur die blinders van waarneming manifesteer. In die herhalingsproses word, volgens Breithaupt, die strategiese doelwitte nagestreef, om ou handelinge te herhaal wat in 'n vaste raamwerk 'n mate van stabiliteit in die hand werk. ${ }^{8}$ Herinnering word tans merendeels gebruik in die plek van historiese bewussyn omdat laasgenoemde begrip in die konteks van meervoudige aanwending van verlede-indrukke in 'n verskeidenheid wetenskaplike rigtings, as meer gepas gereken word.

Hedegeskiedenis, is daarop afgestem om op sigself aan 'n begrip vir die hede 'n bepaalde historiese status toe te ken. Geskiedenis as dissipline, word aanvaar, is daartoe in staat om die hede te verstaan. Deur die aanloop tot die hede te verstaan, word geredeneer, is die historikus daartoe in staat om 'n basis van begrip te vestig wat konteks aan die onmiddellike gebeure te gee. Dit lei tot die skepping van 'n grenslose hede, volgens Harootunian. ${ }^{9}$ Klassieke aannames oor die afbakening van geskiedenis, as synde ' $n$ dissipline wat bloot op die verlede en die hede konsentreer, word afgetakel met die doel om 'n diskoers te skep wat 'n platform vir meervoudige tydservarings bied. Spiegel reken dit is grootliks as gevolg van die paradoksale kontekste wat deur De Certeau uitgewys is dat hierdie veranderinge met betrekking tot persepsies oor geskiedenis aan die orde gekom het. ${ }^{10}$ Dit het in 'n groot mate ook baie te make met die wyse waarop die hede eise aan die mens in 'n bestaanswerklikheid stel waar die implikasies van opeenvolgende en onmiddellike gebeure vereis dat daar van andersoortige en selfs alternatiewe perspektiewe ook kennis geneem word. 'n Magdom kommunikatiewe media, wat wissel van radio, televisie, gedrukte media (koerante en tydskrifte) tot selfoontegnologie en rekenaargebaseerde internettegnologie, (bv. blogs en YouTube) het meegebring dat die hede en verlede op 'n virtuele wyse ineengeskakel is. ${ }^{11}$ Moderne kommunikasiemedia word gekenmerk deur 'n onmiddellikheid wat voorheen bykans ondenkbaar was. Response op gebeure in die hede is dadelik beskikbaar. Dit het ook 'n globale impak - afhangende van die relatiewe belangrikheid van die gebeurtenis.

7. TE Førland, "Mentality as a social emergent: Can the Zeitgeist have explained power?” in History and Theory, 47(1) February 2008, p, 53.

8. F Breithaupt, "The invention of trauma in German Romanticism, in Critical Inquiry, 32(1), Autumn 2005, p. 83.

9. H Harootunian, "Remembering the historical present" in Critical Inquiry, 33, Spring 2007, pp. 471-494.

10. GM Spiegel, "Revising the past/revisiting the present: how change happens in historiography" in History \& Theory, 46, (4), December 2007, pp. 4-5.

11. Vir meer oor aspekte van hierdie kompleksiteit wat 'n magdom metodologiese implikasies vir die dissipine van geskiedenis het, kyk bv. C Classen en W Kansteiner, "Truth and authenticity in contemporary historical culture: an introduction to historical representation and historical truth" in History \& Theory, 48(2), May 2009, pp. 1-4; G Fogu, "Digitalizing historical consciousness" in History \& Theory, 48(2), May 2009, pp. 103-121. In wese gaan dit daaroor dat die media wat tans bykans onmiddellik beskikbaar is om kommunikasie moontlik te maak oor 'n histories betekenisvolle gebeurtenis kan op 'n magdom maniere digital ontgin word. Gevolglik is dit belangrik om kennis te neem dat hierdie vorm van geskiedskrywing baie meer op hede-indrukke vir insigte voorsiening kan maak. 
In hierdie bespreking word veral op die tegnologiese verskynsel van infrastruktuur gelet. In die onderwerp onder bespreking - elektrisiteitsvoorsiening - het dit gegaan oor volhoubaarheidskrisis van 'n noodsaaklike diens. In enige moderne samelewing is infrastrukturele goedere en dienste van besondere waarde. Wat plaaslike owerheidsdienste betref, word aanvaar dat 'water en ligte' 'n vanselfsprekende diens is wat aan plaaslike inwoners, sakelui en vervaardigingsaanlegte gelewer moet word. In wese is plaaslike gebruikers - mits hulle betaal - daarop geregtig om 'n betroubare instandhoudingsdiens rondom elektrisiteit, water, sanitasie, rommelverwydering, die versiering en versorging van openbare ruimtes en kommunikasieweë van die plaaslike owerheid te verwag. Die elektrisiteitskrisis van 2008 was ' $n$ besondere geleentheid om kennis te neem van die wyse waarop die samelewing reageer op klaarblyklike aanduidings van infrastruktuurverval.

Die etimologie van die term infrastruktuur word in die algemeen herlei na die begin van die twintigste eeu toe die begrip wat eers in die arsenaal van kennis in strategiese militêre teorie gebruik is, as gevolg van die positivistiese tendense, in algemene wetenskapsbeoefening na 'n magdom dissiplines oorgedra is. ${ }^{12}$ Dit het, soos in die geval van die term 'natuurlike hulpbronne' onderdeel geword van 'n teoretiese glossarium van begrippe in die neo-klassieke ekonomie waar deterministiese metingsinstrumente ontwikkel is om die administrasie en bestuur van owerheidsienste verstaanbaar te maak. Die gekombineerde gebruik van kennis, tussen die dissiplines van ekonomie, rekeningkunde, owerheidsadministrasie en moderne ingenieurswese het hierdie innovasies genoodsaak. ${ }^{13}$

In die twintigste eeu het Suid-Afrika 'n besondere infrastruktuur van dienste ontwikkel. By nabaat val dit op dat die land, ten tyde van die politieke omskakeling in 1994, die beste infrastruktuur in Afrika gehad het. Dit is nie vreemd nie. In die vorige bestel het in Suid-Afrika 'n sekurokratiese sisteem bestaan wat aan een van die wesentlike vereistes vir 'n gevorderde moderne tegnologiese stelsel voldoen. Die tegnologiehistorikus, Edgerton, bring sekurokrasie regstreeks in verband met kraginfrastruktuur. Hy verduidelik dat ten einde in die vraag te voorsien word infrastruktuur (in moderne ontwikkelde state) op 'n grootse skaal gevestig. Dit is interaktief en almal is daarop aangewese. Gedurende die twintigste eeu

This led to ever greater danger of failure since a failure could lead to total breakdown. The consequence was not only the need for vigilance and maintenance of the technology, but a society itself increasingly disciplined to avoid breakdowns. A society with nuclear power stations was, in this view a society that needed to be heavily policed. ${ }^{14}$

12. Anon, "Infrastructure" in Online etymology dictionary by http://www.etymonline.com/index. php?term=infrastructure (Geraadpleeg 2009.11.18).

13. Hierdie is 'n proses wat vandag steeds onverpoosd voortgaan en onder meer in die dissipline van transdissiplinêre navorsing aandag geniet. Kyk o.m. A Donovan, "Thinking about engineering” in Technology And Culture, 27(4), October 1986, pp. 674-679; IO Baker, "Engineering education in the United States at the end of the century” in Science, New Series, 12(305), 1900.11.02, pp. 666-674.

14. D Edgerton, The shock of the old: technology and global history since 1900, Oxford University Press, Oxford, 2007), pp. 76-77.

15. Kyk L Venter, When Mandela goes: the coming of South Africa's second revolution, (Doubleday, pp. 21-22. 
Vanaf 1994, nadat die burgerlike bevolking daarin geslaag het om die ideale van demokratiese vryheid en respek vir universele menseregte voorop te stel, het waarnemers van die post-apartheid Suid-Afrikaanse samelewing veral gefokus op die instandhouding en uitbreiding van infrastruktuur. Die doelwit was om ' $n$ indruk te vorm oor die wyse waarop die land besig was om te verander. Die stille dinamiek ${ }^{15}$ van absorpsie en ineenskakeling van dienslewering, huisvesting en die uitbreiding van ekonomiese welvaart vir almal, het beteken dat sisteme wat oorspronklik bedoel was om 'n bevoorregte gemeenskap van nagenoeg 7 miljoen mense, hul nywerhede en handelsektore van diens te wees, nou uitgebrei moes word om tot die voordeel van meer as 40 miljoen mense in totaal te strek. Elektrisiteitsdienste was een van daardie dienste. Ofskoon dit meer as toereikend was tydens die oorgang in $1994,{ }^{16}$ was die belangrikste vereiste dat dit a) in stand gehou word; en b) voortdurend uitgebrei word met die doel om, soos in die geval van ontwikkelde state 'n wesentlike rugsteunvoorraad in noodgevalle beskikbaar te hou. ${ }^{17}$ In hoeverre dit plaasgevind het word vervolgens belig.

\section{Tydsverplasing en narratief}

Verplaas uself vir ' $n$ wyle, in die toekoms. Dit is die jaar 2018. U ervaar die behoefte om, as onderdeel van 'n geskiedenis oor Suid-Afrika, 'n begrip te vorm van hoe die mense van weleer 'n energiekrisis ervaar het.

Die historikus sou tipies verduidelik dat die eerste paar maande van 2008 gekenmerk is deur' $n$ politieke magstryd in die geledere van die regerende ANC-alliansie. Die land se ekonomie het, ná 'n tydperk van ongekende ekonomiese groei, gesukkel om te midde van stygende brandstofpryse, gerugte van voedseltekorte en 'n resessie in die Verenigde State van Amerika, kop bo water te hou. 'n Misdaadgolf wat reeds 'n geruime tyd aan die orde was, het meedoënloos duisende Suid-Afrikaners daagliks aan trauma blootgestel. Rassisme het ook kop uitgesteek. Die grondslae van 'n betreklike jong SuidAfrikaanse kultuur van menseregte is openlik bevraagteken.

Dit was onder hierdie omstandighede dat die eerste kragonderbreking op 18 Januarie 2008 plaasgevind het - die soort krisis wat Bodanis as 'ondenkbare chaos' beskryf. ${ }^{18}$ Die publiek is vooraf daarop bedag gemaak, ${ }^{19}$ maar die feit dat daar'n onmiddellike en geskokte respons aan die kant van die breë samelewing was, ${ }^{20}$ was die resultaat van diepliggende faktore. Dit kon terugherlei word na die era van die eerste veelrassige nasionale demokratiese verkiesing in 1994. Binne'n betreklike kort tydperk het die uiterlike manifestasies van verval ingetree. Staatsgeboue het agteruit gegaan. Basiese diensleweringsfunksies soos

16. A Russell, "S Africa eyes rationing to end power cuts" in Financial Times, 2008.01.23 by http://search.

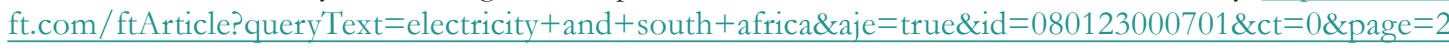
(Geraadpleeg 2008.0505).

17. G Monbiot, Heat: how to stop the planet burning, (Allan Lane, London, 2006), pp. 107-09.

18. D Bodanis, Electric universe: the shocking true story of electricity, (Little Brown, London, 2004), pp. 1-2.

19. S van Wyk, "Beurtkrag kom in middle Januarie" in Beeld, http://152.111.1.251/argief/berigte/ beeld/2007/12/28/B1/4/svwKRAG3.html

20. C Claassen, “'Belaglik'; 'nie goed nie'; 'Maak seer'; 'naar”' in Beeld, 2008.01.18 by http://152.111.1.251/ argief/berigte/beeld/2008/01/19/B1/6/tcckragpt.html 
water, sanitasie en elektriese dienste het, weens 'n groot toename in gebruik en swak instandhouding, begin probleme gee. Veral die swak toestand van paaie het 'n bron van kommer geword. ${ }^{21}$ Groot slaggate het, namate die land se verkeersweë meer verkeersdruk moes dra en instandhouding verminder het, 'n gewilde onderwerp van bespreking geword. Op die uitvoerende van owerheidsdienslewering, het noodsaaklike departementele dienste, soos gesondheid en welsyn, plaaslik, provinsiaal en nasionaal drasties verander. Terwyl baie gedoen is om die lewe van swart Suid-Afrikaners te verbeter, is dikwels nagelaat om die bestaande openbare voorstedelike fasiliteite van hoofsaaklik blanke Suid-Afrikaners in stand te hou. Reeds in die vroeë jare van post-apartheidsregering het geïsoleerde kragonderbrekings sporadies plaasgevind. Dan is daar aan die kant van die kant van die staatsonderneming, die elektrisiteitsvoorsieningskommissie (Eskom) in die openbaar verskoning gemaak. In die reël was daar redelike aanvaarding. Opsluit het dit gegaan oor 'n nuwe bedeling en meer mense moes toegang tot dienste kry. Belangriker, was die feit dat die land in 'n fase van integrale oorgang was.

In die vorige bestel het die regering in die gees van 'n propaganda-sindroom van die 'totale aanslag' omvattend voorsiening gemaak vir elektrisiteitsdienste - in so 'n mate dat daar teen 1994 letterlik 'n oormaat van elektriese krag op die nasionale raamwerk beskikbaar was. ${ }^{22}$ Indien daar' $n$ kragonderbreking was in die jare en maande voor die verkiesing, het die land se inwoners sonder meer tot die gevolgtrekking gekom dat dit ' $\mathrm{n}$ sekuriteitskwessie was en dat die gebeurtenis moontlik aan terreurdade gekoppel kon word. ${ }^{23}$

In die nuwe bedeling was 'n nuwe stel kriteria aan die orde. Die regering het onderneem om krag aan voorheen benadeelde mense te gee. Daarmee saam het ' $n$ mentaliteit posgevat waarin kompensasie as wesentlike motivering vir spesiale dienslewering geregverdig is. Die voorsiening van infrastruktuurdienste is gereken as 'n manier om te kompenseer vir dit wat in die verlede op 'n magdom ander terreine vir voorheenbenadeeldes verstoke was. ${ }^{24}$ Dit was die soort mentaliteit wat volgens Fisher bewustelik of onbewustelik posvat om 'n voorgestelde gebrek of tekort, hetsy geestelik of fisies op 'n andersoortige manier te bevredig. ${ }^{25}$ Ofskoon die meerderheid nuwe kraggebruikers nie die nodige geld gehad het om daarvoor te betaal nie, het plaaslike en streeksowerhede die taak gehad om te sorg dat dienste gelewer word, al was daar nie pariteit tussen gebruik- en vereffeningspatrone nie.

Oorbenutting van beskikbare krag het gevolg, veral vanaf 2002, toe die land 'n ekonomiese groeifase betree het. ${ }^{26}$

21. Kyk bv. Anon., "Grootste slaggat in Afrika?” in Beeld, 2008.03 .03 by http://www.news24.com/Beeld/My_ Storie/0,3-2053_2281310,00.html

22. NoseArk, "Crisis? What crisis?" in Noseweek, 102, April 2008 by http://www.noseweek.co.za/article, php?current_article $=1688$ (Nagegaan 2008.05/08).

23. Kyk SM Fourie, Die impak van militêre aktiwiteite op die Vaaldriehoekse samelewing in die tydperk 19741994 (PhD, PUCHO [tans NWU], Vanderbijlpark 2002), pp. 62-4, 364-6.

24. M Fleshman, Bitter inheritance: overcoming the legacy of apartheid, (Africa Fund, New York, 1993), p. 3.

25. C.S. Fisher, "Comment on 'anxiety': compensation in social history" in Journal of Social History 33(1), 1999, p. 143.

26. M Peel, "Economic surge shorts out suppliers" in Financial Times, 2007.06 .05 by http://search.ft.com/ iai?referer $=$ http $\% 3 \mathrm{~A} \% 2 \mathrm{~F} \% 2 \mathrm{Fsearch} . \mathrm{ft} . \mathrm{com} \% 2 \mathrm{Fsearch} \% 3 \mathrm{Fquery}$ Text $\% 3$ Delectricity $\% 2 \mathrm{Band} \% 2 \mathrm{Bsouth} \% 2$ Bafrica $\% 26$ aje $\% 3$ Dtrue $\% 26 \mathrm{dse} \% 3 \mathrm{D} \% 26 \mathrm{dsz} \% 3 \mathrm{D} \&$ page $=3 \& q u e r y$ Text $=$ electricity + and + south + africa\&lo cation $=$ http $\% 3 \mathrm{~A} \% 2 \mathrm{~F} \% 2 \mathrm{Fsearch} . \mathrm{ft} . \mathrm{com} \% 2 \mathrm{FftArticle} \% 3 \mathrm{Fquery}$ Text $\% 3$ Delectricity $\% 2 \mathrm{Band} \% 2 \mathrm{Bsouth} \% 2 \mathrm{Bafri}$ ca $\% 26 a j e \% 3$ Dtrue $\% 26 i d \% 3$ D070605000886\%26ct $\% 3$ D0 $\% 26$ page $\% 3$ D3\&aje $=$ true \&ct $=0 \&$ rid $=070605000886$ 
Gesien teen 'n breër agtergrond was die tydperk ook gekenmerk deur 'n toenemende kultuur van globalisering. Mense se alledaagse beleweniswêreld is indringend daardeur beïnvloed. Duisende SuidAfrikaners, veral jongmense, het jaarliks die land verlaat. Ontevredenheid met die bewoningsruimte van die hede, het Suid-Afrikaners, soos mense in alle wêrelddele, aangespoor om blyplek in ander lande te gaan soek. Die politieke speelveld van die hede het die terrein geword waarop mense aan die suidpunt van Afrika, hulle werklikheidsbesef geskoei het. Volgens Harootunian word dié soort mentaliteit gekenmerk deur spontane herinneringstrategieë in die samelewing wat dui op 'n hedegeskiedenis waarin daar ' $\mathrm{n}$ toenemende afsondering van die self, op die voorgrond tree. ${ }^{27}$ Die eksistensialistiese kapsule van bestaan in die geslote lewensruimte van die werk- en woonplek, het vir menige SuidAfrikaner 'n vesting geword teen die aanslae van 'n 'onverstaanbare wêreld' daarbuite. Die grense tussen die verlede en hede het in so 'n mate verval dat toekomsverwagtinge verstar geraak het. In werklikheid was dit nie nodig vir die moderne Suid-Afrikaner om noodwendig in ' $n$ bepaalde fisiese ruimte te wees waarmee daar ' $n$ sterk historiese vereenselwiging en binding bestaan nie. Veel eerder het dit gegaan oor 'n ruimte wat veralgemenend as 'n kantoor, 'n woonplek en of 'n openbare ruimte bestempel kon word. Kommunikatiewe bindinge (verbindingstegnologie) met die Heimat was danksy die internet volop. Dit was ook virtueel en onmiddellik.

Anders as negentiende eeuse beriggewing oor byvoorbeeld oorlogsgeweld en natuurrampe, wat eers lank ná die tyd van die gebeurtenis onder die aandag van die publiek gebring is, het die mens van 2008 in die virtualiteit van 'n nuwe totale wêreldervaring gestaan. Die enigste liggaamlike verskansing wat die mens aan die begin van die 21 e eeu gehad het, was die feit dat daar van nuusgebeure, in die veiligheid van 'n bekende lewensruimte tipies voor 'n rekenaar- of televisieskerm, kennis geneem is. Virtuele werklikheid was in baie opsigte net so traumaties vir die waarnemer as wat dit vir die aktiewe deelnemer aan die gebeure wat in miljoene voorkamers wêreldwyd gebeeldsend is. Interpretatiewe gemeenskappe het oor 'n magdom grense heen op blogs ${ }^{28}$ en spesiale webwerwe ${ }^{29}$ gesprek gevoer oor die vrese waarmee in verskillende wêrelddele geworstel is. 'n Goeie vorbeeld is die Suid-Afrikaanse kragonderbrekings van 2008 wat selfs die onderwerp van 'n reeks blitsfilms wat op YouTube was. ${ }^{30}$

\section{Historiese oorsake vir die elektrisiteitskrisis}

Een van die uitstaande kenmerke van die kragonderbrekings was die feit dat apartheid nie die skuld gekry het vir die agteruitgang van die kraginfrastruktuur nie. In 'n land waar voortdurend op die euwels

27. H Harootunian, "Remembering the historical present" in Critical Inquiry, 33(3) March 2007, pp. 471-494.

28. Kyk byvoorbeeld veral berigte met'n omstrede strekking op die webblad van The Times (dit is ook die webblad van Sunday Times) waaromheen daar lang ritse van gesprekvoering plaasgevind het. Byvoorbeeld Wild frontier, "Electricity price hike: Eskom keeps reason secret" in The Times, 2008.04.08 by http://blogs.thetimes.co.za/ hartley/2008/04/08/electricity-price-hike-eskom-keeps-reason-secret/ (Geraadpleeg 2008.05.13); The Wild Frontier, "Load shedding is now a national disgrace" in The Times, 2008.01.17 by http:/ / blogs.thetimes.co.za/ hartley/2008/01/17/load-shedding-is-now-a-national-disgrace/ (Geraadpleeg 2008.05.13); W Swart, "Get the lights off now!” in The Times, 2008.02.06 by http://www.thetimes.co.za/News/Article.aspx?id=699527 (Geraadpleeg 2008.05.13).

29. Kyk bv. Eskom sucks by http:/ / www.eskomsucks.co.za/ (Geraadpleeg 2008.05.12); Solidariteit, Eskomstories by http:/ / www.eskomstories.co.za/argief.htm (Geraadpleeg Maart-Mei 2008).

30. Voorbeelde van video-opnames is te vinde by http:/ / www.youtube.com/watch?v=N8-tO2dc_V0 (Nagegaan 2008.03.09). 
van apartheid gehamer is wanneer eietydse knelpunte in historiese konteks geplaas moes word, was dit vreemd om in die media waar te neem dat daar wel iets goeds was wat in die vorige bestel deur die destydse Nasionale Party (NP) -regering onderneem is. 'n Briefskrywer aan Sowetan, het byvoorbeeld verklaar:

\begin{abstract}
(W)e cannot continue living off apartheid's capital forever. Eskom's electricity crisis has taught us that investment and maintenance of the national infrastructure cannot be ignored forever ... Now it's time for hardnosed frugal governance. The infrastructure that makes us the most dynamic economy in Africa must be maintained and improved .... ${ }^{31}$
\end{abstract}

Aanvanklik is die gebrek aan toereikende kragvoorsiening eenvoudig toegeskryf aan meer intensiewe gebruik as gevolg van die snel ekonomiese on twikkeling wat die land sedert 2002 deurgemaak het. Namate meer inligting in die media oor die omvang van die krisis deurgegee is, het kundiges kommentaar begin lewer. Prof. Anton Eberhard van die Universiteit van Kaapstad het ' $n$ analise gedoen van die toedrag van sake in die Eskomstrukture van kragvoorsiening op die dag van 28 Januarie 2008. Sy berekeninge het op die volgende neergekom: Eskom kapasiteit (Kraginvoere bygereken) $=39$ 855MW; ${ }^{32}$ Bedryfsreserwe $=$ 1800MW; Beoogde instandhouding = 3725MW; Onderbrekings = 4235MW; Verminderde kapasiteit as gevolg van bv. nat of geen steenkool) $=2694 \mathrm{MW}$; en Totale beskikbare kapasiteit wat nie beskikbaar was nie $=31$ persent. Die afleiding wat daaruit gemaak is, was dat dit op die betrokke tydstip baie sleg met Eskom gegaan het. ${ }^{33}$ In wese was dit 'n uitsonderlike toestand wat eintlik, deur doeltreffende bestuur, voorkom kon gewees het. 'n Ander akademikus het tot'n soortgelyke gevolgtrekking gekom. Eskom se besuur het foutiewe aannames gemaak:

The parastatal's celebrated status as a low-cost supplier of electricity was always based in part on apartheid-era overinvestment, abundant surface coal, state debt write-offs, a high tolerance for pollution, and exemptions from taxes and dividend payments. ${ }^{34}$

Ingenieurs wat in kragleweringsektor werksaam was, het die knelpunt na instandhouding herlei. Daar is gewys op 'n ouditverslag van die Suid-Afrikaanse Instituut vir Elektroniese Ingenieurs wat reeds in 2007 inligting oor die swak instandhouding van die land se elektrisiteit-infrastruktuur verstrek het. ${ }^{35}$ Daar is destyds voorgestel dat R1 miljard so spoedig moontlik bestee word om die probleem

31. Korrespondensie: Sowetan - Redakteur, "Pothole blues" in Sowetan, 2008.04.03 by http://www.sowetan. co.za/Feedback/Article.aspx?id=739371 (Geraadpleeg 2008.05.08).

32. $\mathrm{MG}=$ Megawatt.

33. V de Klerk, "Retailers still feel Eskom blues" in News24, 2008.05.05 by http://www.news24.com/News24/ South_Africa/Power_Crisis/0,2-7-2335_2316870,00.html (Geraadpleeg 2008.05.10).

34. A Butler, "How Eskom, state indecision plunged SA into darkness" in Business Day, 2008.03.03 by http:// www.businessday.co.za/articles/topstories.aspx?ID=BD4A718702 (Geraadpleeg 2008.05.01).

35. In 2009, rondom 'n krisis waartydens die destydse HUB van Eskom, mnr Jacob Maroga, in die spervuur gekom het, is bekend gemaak dat me Susan Olson reeds op 19 Julie 2007 Maroga daarvan in kennis gestel het dat die kragsentrales weens 'n steenkooltekort sou kon ineenstort. Hy het agter nie daarop ag geslaan nie. Kyk J de lange, "Eskom-direksie wroeg oor Maroga" in Sake24.com, 2009.1031 by http://www.sake24.com/ articles/default/display_article.aspx?Channel=News_Sake-Vir-Leke\&ArticleId=6-100_2559516\&IsColum nistStory=False (Geraadpleeg 2009.12.07). 
aan te spreek. Voorts moes die staat jaarliks R422 miljoen bestee om noodsaaklike instandhouding te doen. ${ }^{36}$ Plaaslike opnames het ook die gevaartekens uitgelig. In Februarie 2008 is 'n subkomitee van die Kaapstadse stadsraad ingelig dat minstens 17 kragonderbrekings in 2007 deur gebreke in die toerusting veroorsaak is. Arbeidstekorte en die gebrek aan tegniese kundigheid het omstandighede net vererger. ${ }^{37}$

Die joernalis, Peter Bruce, het die geskiedenis van die 2008-kragonderbrekings as volg gesien:

\begin{abstract}
What happened in SA is that the ANC, or at least the exiled part of it, got handed the country on a plate by Afrikaner nationalists for whom apartheid had become too expensive and who saw in the ANC they were negotiating with some echoes of themselves... They (die nuwe regering) approached the running of some of our big institutions and industries with an insouciance that looked seriously cool for a while. This was going to be such a breeze. The whites were ushered out of hospitals and schools, boardrooms and government departments. But something important had been forgotten... It was that when things get difficult, when crises arise, only one thing matters and it isn't the colour of your skin or even your qualifications. It's experience - the quality of having seen such a situation before or watched someone else solve it. Did the ANC rush at transformation too quickly or, at least, fail properly to balance the need for legitimacy in institutions with the need to retain experience and memory? Those old Nat bureaucrats may have been racist but they were used to taking orders and they would have done what they were told. New black legitimacy and old white experience could have made this country impervious to economic or political storm. ${ }^{38}$
\end{abstract}

Nadat die era van kragonderbrekings (aan die einde van April 2008) formeel ten einde gekom het en die land se politieke leiers toenemend na die 'belhamels' begin soek het wat na bewering vir die krisis verantwoordelik was, is geredeneer dat dit in wese oor vals voorstellings van bestuur gegaan het. Verklikkers in Eskom ${ }^{39}$ het bewyse gehad dat die bestuur minder geld op infrastruktuur en instandhouding investeer het. Jaarverslae is uitgebring wat op groot winste gedui het. Bestuur het hulself daardeur bevoordeel. Hulle het op groter bonusse aanspraak gemaak. ${ }^{40}$ Teen Mei 2008 was die krisis so verpolitiseer dat die historiese oorsake vir die kragonderbrekings 'n belangrike tema was in die suiweringsproses wat in die geledere van die regerende ANC-SAKP-COSATO-alliansie aan die orde was. ${ }^{41}$

36. M le Roux, "SA facing 'multiple power crises"' in Business Day, 2008.02.12 by http://www.businessday.co.za/ articles/topstories.aspx?ID=BD4A703946 (Geraadpleeg 2008.05.01).

37. A Powell, "Cape Town neglect blamed for blackouts" in The Cape Times, 2008.02.05, p. 1 by http://www. iol.co.za/index.php?set_id=1\&click_id=3053\&art_id=vn20080205062712118C201900 （Geraadpleeg 2008.05.04).

38. P Bruce, "The thick end of the wedge" in Business Day, 2008.03.17 by http://www.businessday.co.za/ articles/topstories.aspx?ID=BD4A728374 (Geraadpleeg 2008.04.29).

39. Die mense het teen Meimaand begin deurloop onder die bestuur van Eskom. Kyk A Schoeman, "Fluitjieblasers 'loop deur"' in Beeld, 2008.05.11 by http://www.news24.com/Beeld/Kragkrisis/0,23-2365_2320486,00. html (Geraadpleeg 2008.05.13).

40. Anon., "Eskom whistles in the dark" in Noseweek. 103, May 2008, pp. 7-10; M Malefane, "ANC probes Eskom fat cats" in The Times, 2008.05.13 by http://www.thetimes.co.za/News/Article.aspx?id=764161 (Geraadpleeg 2008.05.13).

41. Redaksionele kommentaar, "Krag-geheime" in Beeld, 2008.05.12 by http:/ / www.news24.com/Beeld/Opinie/ Hoofartikels/0,3-2085-65_2321157,00.html (Geraadpleeg 2008.05.13). 


\section{Samelewingsmentaliteite}

'n Uitstaande kenmerk van die kragonderbrekings was dat dit tot buitengewone ontevredenheid en gefrustreerdheid in groot dele van die samelewing aanleiding gegee het. Een van die tergende vrae wat ontstaan is: waarom het die samelewing so gereageer? Dit kon deels toegeskryf word aan die gewaarwording dat ' $n$ alledaagse lewenswyse skielik geraak is deur 'n krisis wat mense. Daar is geredeneer dat dit eintlik nie veronderstel was om plaas te vind nie. Ongerief het mense kwaad gemaak. Daar was ook andersoortige omstandighede. Die feit dat daar nou tye was waarin mense verplig was om (tydens kragonderbrekings) niks te doen nie, het veral in die stedelike omgewing persoonlike en groepsontevredenheid - na aanleiding van kommunikasiegeleenthede - laat posvat.

Die elektrisiteitskrisis was grootliks 'n probleem wat in die stedelike sentra van Suid-Afrika afgespeel het. In 'n meningsopname wat gedoen is, het dit geblyk dat slegs 50 persent van die land se huishoudelike kragverbruikers - waarvan blankes die meerderheid uitgemaak het - wesentlik deur die kragonderbrekings geraak is. Die krisis is in die ergste mate in Gautengprovinsie ervaar. ${ }^{42}$ Dié was, volgens die SuidAfrikaanse Instituut vir Rasseverhoudinge in Johannesburg, die rykste provinsie in die land. In terme van lewenskwaliteit, was Gauteng egter ver agter die Wes-Kaap - veral wanneer die lewensgehalte van welgestelde mense in ag geneem is. Vir behoeftige mense was die Wes-Kaap weer een van die moeilikste streke om 'n menswaardige bestaan te voer. ${ }^{43}$

Die elektrisiteitskrisis was eintlik 'n middelklasprobleem. Woedevlakke onder hierdie groepering SuidAfrikaners het ongekende hoogtes bereik. ${ }^{44}$ Stories van bruilofverrigtinge in die donker, sakelui wat verkies het om hul besigheid oorsee voort te sit en die kabelspoor van Tafelberg wat gaan staan het, was volop - selfs in die buiteland. ${ }^{45}$ Mense het nare ervarings, soos byvoorbeeld om vir ure in hysbakke vasgevang te wees. ${ }^{46}$ Alles het om die gebrek aan krag gewentel. Oral was mense wat emosies van magteloosheid in die werkplek en tuis ervaar het. Simptomaties van 'n klaarblyklike toesand van menslike weerloosheid was byvoorbeeld die dosente aan 'n Johannesburgse universiteit wat aangeraai is om flitse saam te dra wanneer hulle gaan klas gee sodat lesingsale ten minste ordelik tydens beurtkrag ontruim kon word. ${ }^{47}$

Op die paaie was verkeersopeenhopings motoriste se voorland. Die kragkrisis het planne verydel om

42. MAnon., "Gauteng hit most by blackouts" in News24 2008.03.18 by http://www.news24.com/News24/ South_Africa/Power_Crisis/0,2-7-2335_2290289,00.html (Geraadpleeg 2008.05.10).

43. Anon., "The best and the worst regions to live in" in Business Times, 2008.05.054 by http://www.thetimes. co.za/Business/Business'Times/Article.aspx?id=759670 (Geraadpleeg 2008.05.13).

44. Anon., "Cuts hitting on 50\% - survey" in News 24, 2008.03.18 by http://www.news24.com/News24/South Africa/Power_Crisis/0,2-7-2335_2290456,00.html (Geraadpleeg 2008.05.12).

45. SAPA, "Power-cut stories flood website" in News24, 2008.01.22 by http://www.news24.com/News24/ South_Africa/Power_Crisis/0,2-7-2335_2262018,00.html (Geraadpleeg 2008.05.11); Anon., "Lex column: South Africa power cuts" in Financial Times, 2008.01.29 by http:/ / search.ft.com/ftArticle? query'Text=electr $i$ icity + and + south + africa\&aje $=$ true\&id $=080129000239 \& c t=0 \&$ nclick_check=1 (Geraadpleeg 2008.05.05).

46. J Wicks, "Think twice before you enter" in The Mercury, 2008.01.23 by http://www.iol.co.za/index.php?set id=1\&click_id=3045\&art_id=vn20080123065826710C905134

47. Anon., "Wits power memo brings back word from the dead" in Business Day, 2008.02.14 by http://www. businessday.co.za/articles/article.aspx?ID=BD4A70584 (Geraadpleeg 2008.05.01). 
ongelukke op die land se paaie te verminder. ${ }^{48}$ Motoriste in dele van groter Johannesburg het konvensies oor boord gegooi en summier oor nie-werkende verkeersligte gery, sonder om stil te hou. ${ }^{49}$ In die taxisektor van Gauteng het dit chaos veroorsaak. 'n Joernalis het spitstyd in 'n taxi as volg beskryf:

\begin{abstract}
This is the time when passengers pray hard for deliverance from crashes and smashes and death. The surprising thing is that taxi drivers know the rules very well. They do not cross when they are not supposed to. But they have a tendency to go across in a group... Two taxis that have the right of way will go across followed by 10 more. Then the taxis will allow the other three sides to go their own way before sending another 10 through. ${ }^{50}$
\end{abstract}

'n Gewilde vorm van vryetydsbesteding - inkopies (ook in die omgang bekend as 'kleinhandelterapie') - is gebruik om frustrasievlakke te verlig. Suid-Afrikaners het na winkels gestroom om kerse, kragopwekkers, flitse, batterye en soortgelyke noodtoerusting te koop. ${ }^{51}$ Donker inkopiesentra is egter vermy. Die spandabelrigheid van baie mense het ook perke gehad. Hulle maandelikse beursies was besig om te krimp as gevolg van rentekoersverhogings op lenings en oortrokke rekenings. Daarmee saam het brandstofpryse gestyg. Benewens verhoogde elektrisiteitstariewe moes Suid-Afrikaanse verbruikers nou ook met kragonderbrekings saamleef. ${ }^{52}$ Hulle het dus rede gehad om ongelukkig te voel toe dit bekend geword het dat die regering reeds in 'n witskrif van 1998 daarop bedag gemaak is dat 'n elektrisiteitskrisis binne tien jaar kon heers indien die stelsel nie opgegradeer word nie. ${ }^{53}$

Te midde van omstandighede waarin politiek oor 'n breë spektrum op die sosiale onstabiliteit van 'n veranderende samelewing gedui het, het 'n briefskrywer aan Beeld verklaar dat dit belangrik was om bewus te wees van die swaarkry en ontberinge wat swart Suid-Afrikaners in die apartheidsera deurgemaak het. Baie mense het steeds swaar gekry. ${ }^{54}$ Aktiviste het vroeër gewaarsku dat elektrisiteitsvoorsiening en energie in die algemeen 'n luukse was wat welgestelde Suid-Afrikaners as vanselfsprekend aanvaar het ${ }^{55}$. Tydens die elektrisiteitskrisis van 2008 is aangevoer dat die land se behoeftige mense die nadeligste deur

48. Redaksionele kommentaar, "Abandon this foolhardy plan" in Sowetan, 2008.03.20 by http://www.sowetan. co.za/News/Article.aspx?id=730607 (Geraadpleeg 2008.05.02).

49. N Moreosele, "Load shedding throws road rules out the window" in Sowetan, 2008.03.04 by http://www. sowetan.co.za/Columnists/NthabiMoreosele/Article.aspx?id=719018 (Geraadpleeg 2008.05.02).

50. Ibid.

51. Anon., "Gauteng hit most by blackouts" in News 242008.03 .18 by http://www.news24.com/News24/ South_Africa/Power_Crisis/0,2-7-2335_2290289,00.html (Geraadpleeg 2008.05.10).

52. A Sookdin, "Keeping SA in the dark" in News24, 2008.01.17 by http://www.news24.com/News24/ MyNews24/Your_story/0,2-2127-2128_2253730,00.html (Geraadpleeg 2008.05.10).

53. Kyk RSA, Department of minerals and energy, White paper on the energy policy of the Republic of South Africa, 1998 by http://www.dme.gov.za/pdfs/energy/planning/wp_energy_policy_1998.pdf (Geraadpleeg MaartMei 2008); C Coetzee en C Claassen, "Regering het geweet dit kom" in Beeld, 2008.01.23 by http:/ /www. news24.com/Beeld/Suid-Afrika/0,3-975_2257371,00.html (Geraadpleeg 2008.05.13); Kyk ook Another view, "Moving beyond blame: what is required to shore up Eskom" in The Times, 2008.02 .02 by http:/ / www. thetimes.co.za/PrintEdition/Business'Times/Article.aspx?id=697110 Geraadpleeg 2008.05.13).

54. Korrespondensie: Lief vir my land, Pretoria - Redakteur, "Onthou ook apartheid se lyding" in Beeld, 2008.02.19 by http://152.111.1.251/argief/berigte/beeld/2008/02/19/B1/14/tuLyding18feb.html

55. Kyk o.m. D Hallowes and V Munnik, "Peak poison: the elite energy crisis and environmental justice" in The groundWork Report 2007, (groundWork, Pietermaritzburg, November 2007). 
kragonderbrekings geraak is. ${ }^{56}$

Die media het vasgestel dat veral agtergeblewe mense aan langer kragonderbrekings as gewone huishoudelike gebruikers onderhewig was. ${ }^{57}$ Daar is kommer oor hierdie toedrag van sake uitgespreek. Veral in die land se metropolitaanse informele nedersettings het swak omstandighede geheers. Inwoners van die Princess plakkerskamp aan die Wesrand het verslaggewers van die Mail \& Guardian vertel dat hulle reeds meer as 12 jaar 'permanente beurtkrag' ervaar het. Hulle het wel van beurtkrag kennis geneem wanneer hulle na die radio luister. In sommige opsigte was hulle beter daaraan toe as mense wat nou onder krisisomstandighede sonder krag moes klaarkom. Die plakkers het reeds lank tevore geleer hoe om sonder krag klaar te kom. Hulle het byvoorbeeld mekaar onderling gehelp. Eienaars van yskaste (wat vermoedelik met kragparaffien werk) het hul toerusting in die reël met ander mense in die gemeenskap gedeel. ${ }^{58}$

Van owerheidsweë is kennis geneem van behoeftige mense. Nadat Eskom aangekondig het dat elektrisiteitstariewe verhoog moes word, ${ }^{59}$ het die regering die versekering gegee dat lae-inkomste huishoudings nie nadelig deur hierdie reëling getref word nie. ${ }^{60}$ Met die kommunikasie van ANCleierskap was daar egter probleme. ${ }^{61}$ Daar was aanduidings van amptelike persverklarings wat botsende boodskappe aan die publiek deurgegee het. Dit het tot verwarring aanleiding gegee. Daarmee saam het die publiek vertroue begin verloor in die vermoë van die regering om die krisis aan te spreek.

Op die oog-af het veral mense in informele nedersettings die toedrag van sake gelate aanvaar. Daar was egter tussendeur duidelike seine dat ook hulle hul woede nouliks kon onderdruk. Dieselfde soort kultuur van verset en protes, wat in die 1980's die land onregeerbaar gemaak het, het weer kop uitgesteek. Soos in die 'ou bestel', is polisie ingeroep om onrus met hardhandige optredes in die kiem te smoor. Onwettige kragaansluitings by hostelle in Gauteng was 'n algemene verskynsel. Vier mense is by geleentheid in Kwa Thema deur elektriese stroom in hierdie aansluitings doodgeskok. Polisie is ingeroep om onrus, wat uit die insident voortgespruit het, te onderdruk. ${ }^{62}$ Voorstedelike treine is aan die brand gesteek omdat verkeer deur kragonderbrekings vertraag is. ${ }^{63}$ Dit het gegaan oor menslike behoeftes aan basiese dienste waarvoor die owerheid tradisioneel verantwoordelik was. Weens die kragonderbrekings was daar nou niks. Nog meer, dit het gegaan oor die realisering van menswaardigheid, selfs in agtergeblewe gedeeltes van die samelewing. Die mense het verwag dat hulle pleidooi vir dienslewering ten minste gerespekteer sou word.

56. Anon., “Workers pay more for bosses' energy excess" in Sowetan, 2008.03.14 by http:/ /www.sowetan.co.za/ News/Article.aspx?id=726833 (Geraadpleeg 2008.05.02).

57. Anon., "Outrage mounts over power cuts" in Mail \& Guardian Online, 2008.01.18 by http://www.mg.co.za/ articlePage.aspx?articleid=329931\&area=/breaking_news/breaking_news_business/

58. W Forster en N Ndlovu, “These are the shedded” in Mail \& Guardian Online, 2008.01.26 by http://www. mg.co.za/articlePage.aspx?articleid $=330633 \&$ area $=/$ insight $/$ insight_national $/$

59. M Klein, "Electricity price may rise by $60 \%$ " in Sowetan, 2008.03 .19 by http://www.sowetan.co.za/News/ Business / Article.aspx?id=729824 (Geraadpleeg 2008.05.02).

60. L Ensor, "Poor to be spared Eskom hardship" in Business Day, 2008.03.25 by http://www.businessday.co.za/ articles/topstories.aspx?ID=BD4A732620 (Geraadpleeg 2008.04.29).

61. I Lekota, "Eskom tariff hukes get a no from ANC" in Sowetan 2008.03.20 by http://www.sowetan.co.za/ News/Article.aspx?id=730628 (Geraadpleeg 2008.05.02).

62. Anon., "Cop injured during protests" in News24, 2008.04.22 by http://www.news24.com/News24/South Africa/News/0,2-7-1442_2310300,00.html (Geraadpleeg 2008.05.10).

63. Redaksionele kommentaar, "Torching trains as a vehicle of frustration delivers nothing" in City Press, 2008.01.26 by http://www.news24.com/City_Press/Leaders/0,186-189_2259066,00.html (Geraadpleeg 2008.05.13). 
Briefskrywers aan koerante het die kragonderbrekings beskryf as ' $n$ krisistoestand wat op verval dui. Daar is geredeneer dat die kragonderbrekings net die mees opsigtelike van 'n hele reeks krisisse in die land was. Daar is aangevoer:

\begin{abstract}
The reality is that there is a meltdown in our education system, crime and corruption are rampant, and the nation's infrastructure in total is rapidly crumbling, so that the possibility of effective service delivery becomes more distant by the month. ${ }^{64}$
\end{abstract}

By baie Suid-Afrikaners was daar aanduidings van 'n intense teleurstelling met die toedrag van sake. Kragonderbrekings was die mantra van 'n bepaalde tydsgees. 'n Briefskrywer aan City Press, Machaba Matsapola van Lebowakgomo in Limpopoprovinsie, het verklaar:

Whatever happened to the beautiful democratic country that we were building together as a nation?... One does not need a fortune-teller to see that this country is slowly but surely headed for destruction ... There is no indication that things will be corrected any time soon. It gets even gloomier when one contemplates the future because of the power cuts that are filling our hearts with darkness. ${ }^{65}$

'n Ander skrywer het die kragonderbrekings vergelyk met terreur en van die standpunt uitgegaan dat die nadelige gevolge van onderbrekings baie meer omvangryk as blote dade van terreur was. ${ }^{66}$

\title{
Mentaliteite in die huishoudelike omgewing en die werkplek
}

Dit was in die private sfeer van die huishoudelike omgewing waar 'kragloosheid' intens geregistreer het. Vir die eerste keer in baie jare het dit weer gebeur dat gesinslede in duisende huishoudings met mekaar om die etenstafel gesels het. TV-etes was vir die eerste keer sedert 1975, toe die eerste televisiediens aangebied is, nie meer deel van 'n alledaagse lewenswyse nie. Die raserigheid van 'n magdom elektroniese kommunikasiekanale in die land se woonbuurte het saans stil geword. Dit het plek gemaak vir mensgeluide van gesels en dinge doen. Die geur van braaivleis het plek-plek swaar gehang. Voorstedelike Suid-Afrikaners, wat dit kon bekostig, het by restaurante gaan eet waar kragopwekkers en die nodige toerusting was om voedsel voor te berei. Ander het hul lot bekla oor kos wat nie gaar gemaak kon word nie. Sommige gesinne moes by geleentheid honger gaan slaap. ${ }^{67}$ In die media is resepte gegee van kosgeregte wat sonder hitte voorberei kon word. Die voordele van rou kos is beklemtoon. ${ }^{68}$ Teen Mei 2008 is gewaarsku dat die elektrisiteitskrisis, wat die vooruitsig van duurder kragtariewe ingehou het, sou beteken dat 'n voorbereide

64. R Stone, Johannesburg - Redakteur, "Mbeki’s legacy" in Business Day, 2008.02.05 by http://www.businessday. co.za/articles/article.aspx?ID=BD4A698856

65. Korrespondensie: Machaba Matsapola, Lebowakgomo - Redakteur, "Cry, our beloved country is falling apart” in City press, 2008.02.16 by http://www.news24.com/City_Press/Letters/0,186-247_2272107,00. html (Geraadpleeg 2008.05.13).

66. Korrespondensie: D East, River Club - Redakteur, "Power terrorists" in Business Day, 2008.02.11 by http:// www.businessday.co.za/articles/article.aspx?ID=BD4A703166 (Geraadpleeg 2008.05.01).

67. P Mnisi, Johannesburg - Redakteur, "Power cuts cause lots of stress" in Sowetan, 2008.01.24 by http://www. sowetan.co.za/Feedback/Article.aspx?id=690350 (Geraadpleeg op 2008.02.10.) 
bord kos besig was om 'n luukse te word wat baie mense nie kon bekostig nie. ${ }^{69}$

In die geledere van swart Suid-Afrikaners is gepraat van die 'kersgenerasie'. 'n Vorige geslag het die jongmense van 2008 vertel van die tyd - in die era van apartheid - toe hulle net op kerskrag aangewese was. Die rubriekskrywer Themba Molefe het verduidelik:

Some might still remember the tough days when, as children, they would run to Mapea's General Store down the muddy street to buy two candles at 10c each because the old lady could not afford a whole packet. Enough just to illuminate the most-used of the three or four-roomed houses; and maybe even save them for the next day... Then there was also paraffin. Many used it for their little lamps and the single hotplate equivalent of the township. Remember the treasured Primus stove? In the absence of coal, in many households it doubled up as a heater and for cooking. ${ }^{70}$

Molefe het gewaarsku dat daar teen mentaliteit gewaak moet word. Dit sou dan bloot 'n herhaling word van die soort werklikhede waarmee die gemeenskap destyds moes saamleef. ${ }^{71}$

Suid-Afrikaners het prioriteite raakgesien wanneer dit gegaan oor wie voorkeurbehandeling met kragvoorsiening moes kry. Byvoorbeeld, dit was as vanselfsprekend aanvaar dat kragvoorsiening so omvattend moontlik aan die land se nywerhede en huishoudings voorsien word. In tye van krisis, het een briefskrywer aan 'n koerant verduidelik, moes die voorsiening van krag aan buurlande summier afgesny. ${ }^{72}$ Dit was spoedig ' $n$ politieke kwessie - veral nadat dit bekend geword het dat sommige van Suid-Afrika se buurlande elektrisiteit teen minder as kosprys gekoop het. ${ }^{73}$

Die implikasies van kragonderbrekings vir nooddienslewering het spoedig duidelik geword. Kort nadat 'beurtkrag' ${ }^{\text {'4 }}$ begin het, is kommer uitgespreek wat gaan byvoorbeeld gebeur by hospitale as onderbrekings moes aanhou. Plaaslike owerhede het die publiek die versekering gegee dat voorsorgmaatreëls daarteen getref is. ${ }^{75}$ Dit was egter nie deurgaans die geval nie. In Limpopoprovinsie het 'n vrou wat geboorte moes gee, sonder welslae by drie klinieke aangemeld. Al die plekke het beurtkrag ervaar. Die gevolg was dat sy,

68. Anon., "Try raw food if Eskom fails you" in Sowetan, 2008.02.21, by http:/ / www.sowetan.co.za/GoodLife/ Article.aspx?id=710580 (Geraadpleeg 2008.05.02).

69. Anon., "Disaster waiting to happen"' in News24, 2008.05.02 by http://www.news24.com/News24/South Africa/Power_Crisis/0,2-7-2335_2315408,00.html (Geraadpleeg 2008.05.10).

70. T Molefe, "The candle generation may now shed a lot of fun" in Sowetan, 2008.01.24 by http:/ / www.sowetan. co.za/Columnists/'ThembaMolefe/Article.aspx?id=690485 (Geraadpleeg 2008.03.05).

71. Ibid.

72. P Mnisi, Johannesburg - Redakteur, "Power cuts cause lots of stress" in Sowetan, 2008.01.24 by http://www. sowetan.co.za/Feedback/Article.aspx?id=690350 (Geraadpleeg op 2008.02.10.)

73. S Njobeni, "Household electricity 'too pricey"' in Business Day, 2008.04.25 by http://www.businessday.co.za/ articles/topstories.aspx?ID=BD4A756329 (Geraadpleeg 2008.04.25).

74. 'n Term wat vir die doeleindes van kragonderbrekings deur Eskom ingevoer is.

75. T Monama, "Some hospitals will have power" in Sowetan, 2008.03 .04 by http://www.sowetan.co.za/News/ Article.aspx?id=719210 (Geraadpleeg 2008.05.02). 
onderweg na die hospitaal op Louis Trichardt, aan haar kind in 'n ligte voertuig geboorte moes gee. ${ }^{76}$ By Fourways, in Gautengprovinsie, het 'n pasiënt wat 'n dringende hartoperasie moes ondergaan, vergeefs gewag as gevolg van kragonderbrekings. Eers nadat 'n private nooddiens die plaaslike owerheid geskakel het om op die dringendheid van die operasie te wys, is die krag weer aangeskakel. ${ }^{77}$ Dit het toenemend duidelik geword dat onderbrekings' $n$ wesentlike bedreiging vir die veiligheid van die burgerlike samelewing ingehou het. In Kempton Park is 'n vrou deur dampe van 'n kragopwekker in haar woning oorval. Sy het daarvan gesterf. Haar tienerkind is vir behandeling in die hospitaal opgeneem. ${ }^{78}$

Soos in die huishoudelike omgewing het kragonderbrekings in die semi-private sfeer van die werkplek 'n nadelige effek gehad. Dit is veral deur simptome van depressie gekenmerk. Die bestuurder van 'n eiendomsagentskap in Johannesburg het' $n$ verslaggewer vertel dat kantoorwerkers in die eiendomsbedryf depressief geraak het. Eiendomsverkope het drasties gedaal en mense was angstig om hul wonings te verkoop om na de buiteland te emigreer. Tussendeur moes verkoopspersoneel met probleme van depressie worstel in 'n hoogs mededingende bedryf waar min investeringsgeld en nog minder kopers beskikbaar was. Vir die bestuurder wat daagliks haar personeel moes motiveer, was dit moeilik om die taak uit te voer - veral wanneer beurtkrag in die oggend haar verhoed het om hare te was en elektronies te droog. ${ }^{79}$

'n Voordelige gevolg van die kragonderbrekings was dat mense in kantore vir 'n slag van hulle rekenaarterminale wegbeweeg het en die tyd gevind het om met kollegas te gesels. ${ }^{80}$ Onderliggende frustrasies het egter aanwesig gebly. Een kantoorwerker het in 'n brief aan die media huisgesinne versoek om kragbesparing aktief na te streef sodat sy ten minste soggens met haar werk op kantoor kon voortgaan. ${ }^{81}$

\section{Humor}

In die media is kennis geneem van die feit dat mense swaarkry. Vir die rubriekskrywer, James Clarke, was humor simptomaties van die feit dat die samelewing 'n intense krisis ervaar. ${ }^{82}$ 'n Magdom grappe oor die onderbrekings het in kuberruimte, oor selfone, en in die gedrukte media neerslag gevind. ${ }^{83}$ Onder meer

76. A Matlala, "Baby born in bakkie" in Sowetan, 2008.03.06 by http://www.sowetan.co.za/News/Article. aspx?id=720781 (Geraadpleeg 2008.05.02).

77. S Béga, "No comment yet from Eskom on poisoning" in The Star, 2008.04.26, p. 4 by http://www.iol.co.za/ index.php?set_id=1\&click_id=3053\&art_id=Vn20080426082446772C772085 (Geraadpleeg 2008.05.04).

78. N Nair, "Eskom looking into generator death" in The Times, 2008.04.24 by http://www.thetimes.co.za/ News/Article. aspx?id=756186 (Geraadpleeg 2008.05.01); S Béga, "No comment yet from Eskom on poisoning" in The Star, 2008.04.26, p. 4 by http://www.iol.co.za/index.php?set_id=1\&click_id=3053\&art_ $\mathrm{id}=\mathrm{vn} 20080426082446772 \mathrm{C} 772085$ (Geraadpleeg 2008.05.04).

79. S Mann, "Estate agents soldier on" in Business Day, 2008.04.12 by http:/ / www.businessday.co.za/weekender/ article.aspx?ID=BD4A745204 (Geraadpleeg 2008.04.12).

80. D Gemmel, "Packed back-up plan for increased fitness" in Business Day, 2008.03.26 by http://www. businessday.co.za/articles/healthnews.aspx?ID=BD4A732708 $\quad$ Geraadpleeg, 2008.03.26 (Geraadpleeg 2008.04.29).

81. Korrespondensie: G Schroeder, Enercheck Solutions - Redakteur, "Electricity saving" in Business Day, 2008.03.18 by http://www.businessday.co.za/articles/article.aspx?ID=BD4A729161 (Geraadpleeg 2008.04.29).

82. J Clarke, "Hey Eishkom, we citizens are not amused..." in The Star, 2008.01.24 by http://www.iol.co.za/ general/other/lol_container.php?set_id=40\&click_id=2710\&art_id=vn20080124010100399C915869 
het 'n skrywer in een van vele kletsgroepe verklaar dat die nasionale energiereguleerder net wetgewing teen kragonderbrekings kon deurvoer. Dan sou die krisis iets van die verlede wees. ${ }^{84}$

Die verbruikerskultuur van 'n moderne kapitalistiese samelewing het duidelik nie in die slag gebly nie. Daarvoor het die advertensiemedia en uitgeslape sakeluigesorg. Eenvindingryke motorhandelsonderneming in Gauteng het teen die helfte van Februarie 2008 geadverteer dat as kliënte elektriese kragopwekkers teen R115 000 elk koop, sou hulle 'n nuwe model motor van 2007 gratis op die koop toe kry! ${ }^{85}$

Die joernalis Peter Bruce, was heeltemal oorbluf deur die willekeurige gebruik van beurtkrag, sonder om die publiek behoorlik in kennis te stel. Syns insiens moes Suid-Afrika, net soos die Spanjaarde in Spanje, eerder 'n siesta bedags tussen 12:00 en 17:00 invoer. Mense kon dan voor en ná die siesta volstoom werk en terselfdertyd bydra om krag te spaar

We can save the country. Eskom gets the down-time it requires to patch up its ailing kit and the country gets to take lunch and a nap, as it were. Ask any doctor - a series of catnaps during the day is healthy. And so are street lights at night. ${ }^{86}$

Spotprente was volop. ${ }^{87}$

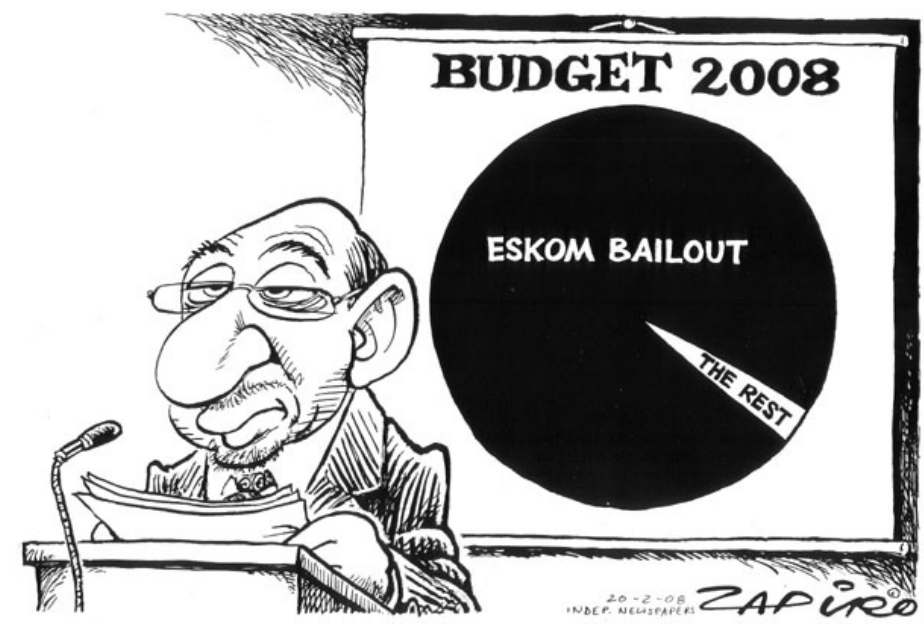

Spotprent 1 Zapiro het die Eskom-effek in die 2008/9-begroting raakgesien. ${ }^{88}$

83. Ibid.; Anon., "Aussie pilot sheds loads of humour on his passengers" in Business Day, 2008.02.07 by http:// www.businessday.co.za/articles/article.aspx?ID=BD4A700740 (Geraadpleeg 2008.05.01).

84. Kletsgroep: "darko" in The Times, 2008.01.20. by http://www.thetimes.co.za/News/Article.aspx?id=685437 (Geraadpleeg 2008.05.01).

85. Advertensie: McCarthy Call-a-Car Direct in die Bidvest handelaarsgroep, "Koop 'n kragopwekker ... en kry 'n gratis 2007 Corolla 1400i” in MotorBeeld, 2008.02.14, p. 24.

86. P Bruce, "The thick end of the wedge" in Business Day, 2008.04.21 by http:/ / www.businessday.co.za/articles/ topstories.aspx?ID=BD4A752680 (Geraadpleeg 2008.04.21).

87. N Jackson, "Beeldforum: Plan is nodig vir al die mis op straat" in Beeld, 2008.04,04 by http://www.news24. com/Beeld/Opinie/Rubrieke/0,3-2085-66_1910966,00.html (Geraadpleeg 2008.05.13).

88. Zapiro in IOL 2008.01.21 by http://gallery.iol.co.za/v/cartoons/zapiro/21_02_2008_zapiro.jpg.html (Geraadpleeg 2008.04.20). 
Mama Taxi het die vrede van buitelandse besoekers aan Suid-Afrika goed saamgevat.
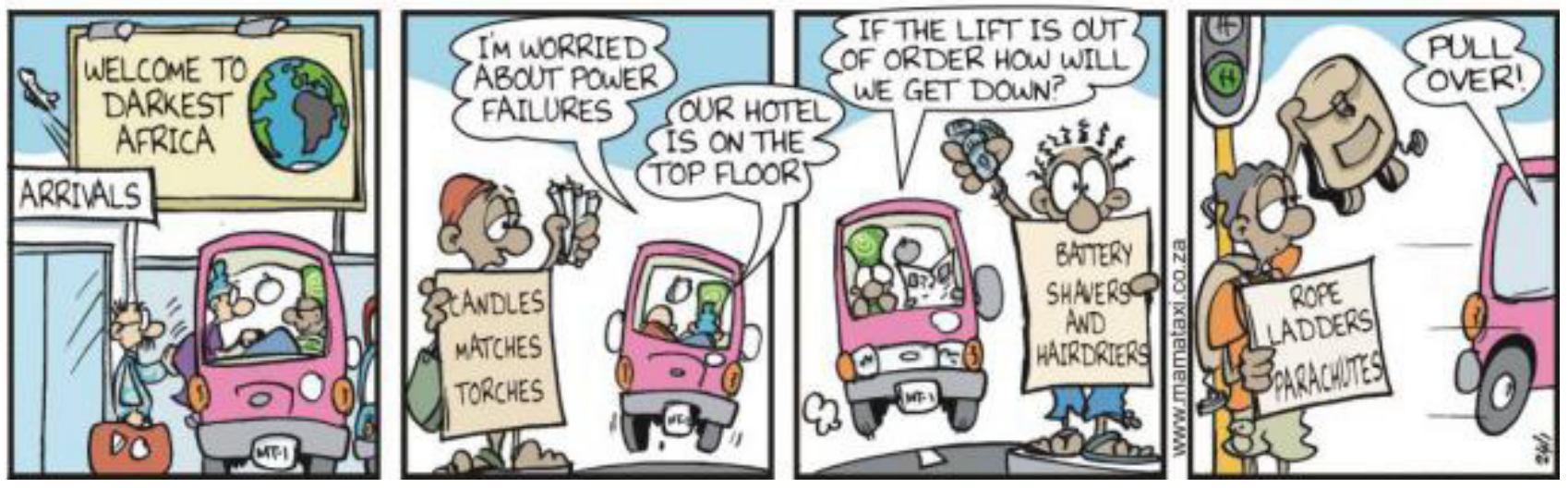

Spotprent 2 Mama Taxi het alternatiewe apparaat se waarde omskryf. ${ }^{89}$

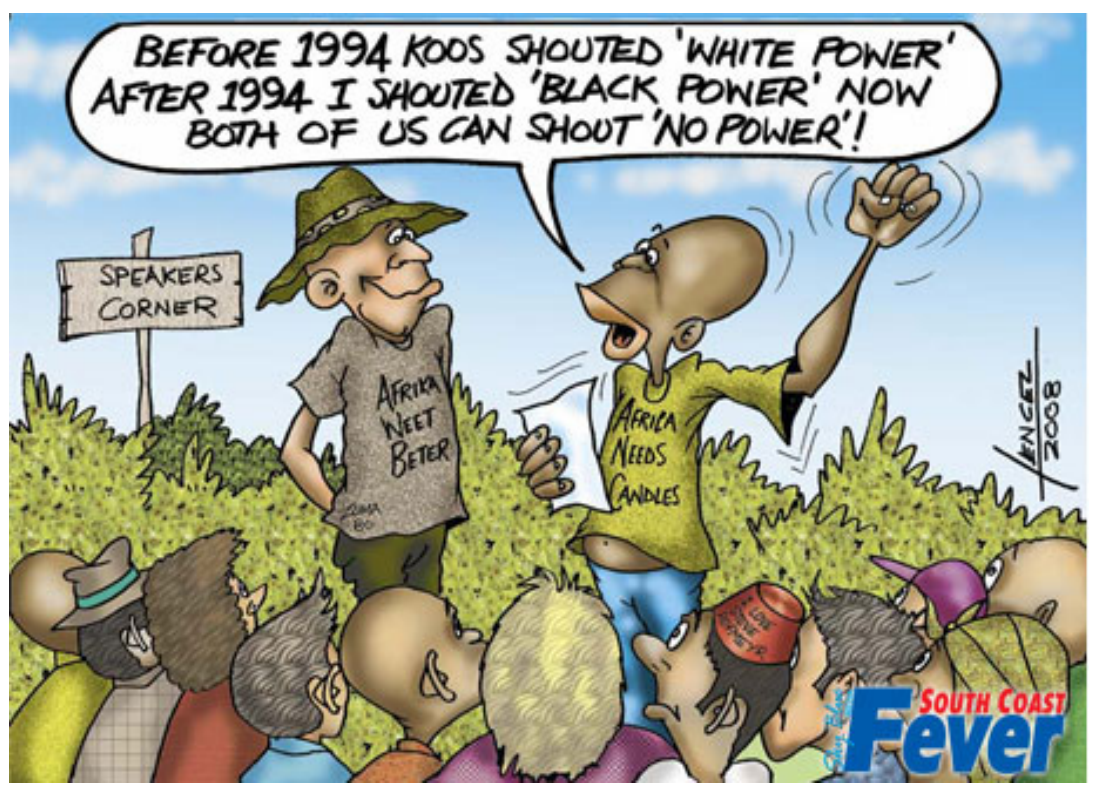

Spotprent 3 Een van drie spotprente op die webwerf van Eskomplain. ${ }^{90}$

Kommunikasiekundiges het die gebruik van humor onder krisisomstandighede aangemoedig. ${ }^{91}$ Sally Haw, wat kennis geneem het van die uitdrukkings op die gesigte van motoriste wat soggens werk toe ry en die liggaamshouding van mense op kantoor wanneer beurtkrag plaasgevind het, het bestuurslui aangeraai om die geestesklimaat van werknemers met humor te probeer verander. ${ }^{92}$

89. Mama Taxi in IOL 2008.01.24 by http://gallery.iol.co.za/v/cartoons/mamastaxi/24_01_2008_mama.jpg. $\underline{\mathrm{html}}$

90. Kyk http:// eskomplain.co.za/fever-cartoons/ (Geraadpleeg 2008.05.14).

91. P Mann, "Eskom must manage outrage as well as outages" in Business Day, 2008.03.11 by http://www. businessday.co.za/articles/topstories.aspx?ID=BD4A725158 (Geraadpleeg 2008.04.29).

92. S Haw, "Managing workplace humour is serious stuff" in Business Day, 2008.04.01 by http://www. businessday.co.za/articles/management.aspx?ID=BD4A738114 (Geraadpleeg 2008.04.29). 


\section{Omgewingsbewustheid en innovasie}

Een van die voordelige gevolge van die kragkrisis was dat Suid-Afrikaners ook in die konteks van kragvoorsiening deur omstandighede gedwing is om omgewingsbewus te raak. Besparingsadvies het gewissel van komberse om warmwaterstelsels en die invoer van fleksietyd op kantoor. ${ }^{93}$ Akademici het daarop gewys dat enige kragbesparingsbeplanning omgewingsvriendelike strategieë in ag moes neem. ${ }^{94}$ Dit het 'n klimaat vir innovasie geskep. Navorsers het aan die hand gedoen dat Suid-Afrika in verskillende dagligstreke gedeel word om die vraag na krag na verskillende tye van die dag te versprei. Duur duplisering van energieproduksie sou ook voorkom word. ${ }^{95}$

Stedelinge het begin dink dat onvolhoubare kragvoorsiening met omgewingsvriendelike tegnologie vervang moes word. Dit is as 'n prioriteit deur 'n koerantleser van Hillbrow beskryf. ${ }^{96}$ Toenemend is aanvaar dat hulpbronne soos water en elektrisiteit beperk is en dat dit noodsaaklik was vir Suid-Afrikaners om oordeelkundig daarvan gebruik te maak. ${ }^{97}$ Briefskrywers aan koerante het staatsdepartemente, sakeondernemings en nywerhede gekritiseer wat saans die ligte van kantore in hul geboue laat brand het terwyl voorstedelike woongebiede straatligte af was om krag te spaar. ${ }^{98}$ Omgewingsjoernaliste het daarop gewys dat volhoubare energiegebruik net haalbaar was mits daar van minder besoedelende kragbronne soos byvoorbeeld windkrag - gebruik gemaak word. ${ }^{99}$ Daar is ook met meer belangstelling as gewoonlik kennis geneem van die sienings van omgewingsaktiviste. ${ }^{100}$

'n Nuwe organisasie 'Green Building Council of SA', is in die lewe geroep om die ontwikkeling, beplanning en stedelike bestuur op 'n meer omgewingsvriendelike lees te skoei. Onder meer het die organisasie hom ten doel gestel om alternatiewe kragbronne en kragbesparende tegnologie te bevorder. ${ }^{101}$ Ontwikkelaars van meenthuiskomplekse het spoedig gereageer op die krisis. Gasstowe en sonpanele, is weens die onbetroubare dienslewering van Eskom, as standaardtoerusting by nuwe behuisingskomplekse ingevoer. ${ }^{102}$

93. Sapa, "Save electricity, or else" in Sowetan 2008.03.04 by http://www.sowetan.co.za/News/Article. aspx?id=719701 (Geraadpleeg 2008.05.02).

94. T Monama, "Call for rationing to save energy" in Sowetan, 2008.01.28 by http://www.sowetan.co.za/News/ Article.aspx?id=692842

95. B Cloete and S Truen, "Lightening the power load with daylight saving" in Business Day, 2008.02.19 by http://www.businessday.co.za/articles/topstories.aspx?ID=BD4A709036

96. Letters to the editor: S'Busiso Xaba, Hillbrow - Editor, "Renewable energy is the way to go" in City Press, 2008.02.02 by http://www.news24.com/City_Press/Letters/0,186-247_2263496,00.html.

97. N Mfusi, "Sigh of relief over end to blackouts" in The Mercury, 2008.05.02, p. 3 by http://www.iol.co.za/ index.php?set_id=1\&click_id=3053\&art_id=vn20080502081246977C808193 (Geraadpleeg 2008.05.04).

98. Korrespondensie: H Watermeyer, Lyndhurst - Redakteur, "Lights-out time" in Business Day, 2008.03.18 by http://www.businessday.co.za/articles/article.aspx?ID=BD4A729189 (2008.03.18).

99. N Jackson, "Beeldforum: Plan is nodig vir al die mis op straat" in Beeld, 2008.04,04 by http://www.news24. com/Beeld/Opinie/Rubrieke/0,3-2085-66_1910966,00.html (Geraadpleeg 2008.05.13).

100. Anon., “Workers pay more for bosses' energy excess" in Sowetan, 2008.03.14 by http://www.sowetan.co.za/ News/Article.aspx?id=726833 (Geraadpleeg 2008.05.02).

101. Anon., "New focus on 'green building"” in Business Day, 2008.02.13 by http://www.businessday.co.za/ articles/property.aspx?ID=BD4A704833 (Geraadpleeg 2008.05.01).

102. J Gray, "Boskruin development raises the bar" in Business Day, 2008.03.28 by http://www.businessday.co.za/ articles/homefront.aspx?ID=BD4A734635 (Geraadpleeg 2008.04.29). 
In gemeenskapsinisiatiewe om die jeug op die noodsaaklikheid vir nuwe innovasie in die wetenskap en tegnologie bedag te maak, is reeds in Januarie 2008 aan die hand gedoen dat gelet word op tegnologie wat alternatiewe bronne van krag kon voorsien. ${ }^{103}$ Daar is kennis geneem en inligting uitgeruil oor die doeltreffendste manier waarop huishoudings te werk kon gaan om elektrisiteit te bespaar. ${ }^{104}$ Onder meer is voorgestel dat: termostate van waterverwarmers laer gestel word; wasgoed in kouewater gewas word; swembadpompe vir bepaalde tye van elke dag afgeskakel word; en kragbesparende gloeilampe geïnstalleer word. ${ }^{105}$ By geleentheid is aan die hand gedoen dat huishoudelike krag gespaar word deur warmwaterstelsels af te skakel. ${ }^{106}$ Dit is 'n standpunt wat spoedig omvattend deur kenners afgemaak is. Interessante inligting is in die media deurgegee om kraggebruik so doeltreffend as moontlik te maak. Heelwat redaksionele ruimte is in koerante daaraan afgestaan. ${ }^{107}$

Van owerheidsweë is stappe gedoen om 'n perk te plaas op toerusting wat krag onekonomies gebruik het. Onder meer het amptenare in die departemente van mineraal- en energiesake, in samewerking met die departement van binnelandse inkomste, gewerk aan wetgewing wat 'n verbod sou plaas op goedkoop huishoudelike toerusting, soos yskaste, wat ondoeltreffend krag gebruik het. ${ }^{108}$ In Februarie 2008 het die Gautengse provinsiale regering aangekondig dat regeringsgeboue volledig van kragbesparende gloeilampe voorsien sou word. ${ }^{109}$ Die gebruik van kragbesparende gloeilampe is vir die eerste keer deur die owerheid ingevoer in 2006 toe kragonderbrekings in die Wes-Kaap aan die orde was. ${ }^{110}$ Teen Maart 2008 het dié provinsie se regering hom verbind tot die ontginning van hernubare energiebronne en 'n projek van stapel laat loop om sonligkrag vir die verhitting van waterstelsels in die woongebied Kwanokuthula in te voer. ${ }^{111}$

Innoverende planne vir grootse projekte wat voorheen as blote toekomsdrome gereken is, is weer opgediep. In Februarie 2008 is bekend gemaak dat Westcor, die Western Power Corridor Company, (Westcor), 'n maatskappy wat etlike jare tevore tot stand gebring is, in die afsienbare toekoms met die derde fase van die Inga hidro-elektriese projek onder die leiding van die Afrika-Unie en deur die bemiddeling van Angola, Botswana, die Demokratiese Republiek van die Kongo, Namibië en Suid-Afrika gaan voer. Die projek wat reeds 'n geruime tyd in die ontwikkelingspyplyn was, het teen 2008 al hoe meer lewensvatbaar geword om die toenemende vraag na elektrisiteit te bevredig. ${ }^{12}$ Lewensvatbaarheidstudies oor die potensiaal

103. Anon., "Young minds challenge" in Sowetan, 2008.01.30 by http:/ / www.sowetan.co.za/News/NationBuilding/ Article.aspx?id=694157

104. Korrespondensie: G Schroeder, Enercheck Solutions - Redakteur, "Electricity saving" in Business Day, 2008.03.18 by http://www.businessday.co.za/articles/article.aspx?ID=BD4A729161 (Geraadpleeg 2008.04.29)

105. Ibid.

106. Redaksionele kommentaar: "Source resources" in Sowetan, 2008.01.24 by http://www.sowetan.co.za/ Feedback / Article. aspx?id $=690357$

107. F Forde, "A-Z of load shedding" in Pretoria News, 2008.p01.25 by http://www.iol.co.za/index.php?set id=1\&click_id=3053\&art_id=vn20080125081012987C990428

108. L Ensor, “Ban looms for power-guzzling appliances” in Business Day, 2008.02.18 by http:/ / www.businessday. co.za/articles/topstories.aspx?ID=BD4A708435 (Geraadpleeg 2008.05.01).

109. Anon., "Shilowa se planne" in Beeld, 2008.02.19, p. 2.

110. T Monama, "Energy-saving plan's green light” in Sowetan, 2008.03.11 by http://www.sowetan.co.za/News/ Article.aspx?id=724100 (Geraadpleeg 2008.05.02).

111. J Davenport, "Western Cape aims to take lead in tackling climate change, energy efficiency" in Engineering News, 2008.05.02 by

112. T Craemer, "Has Inga's time finally arrived" in Engineering News, 2008.05 .02 by http:/ / www.engineeringnews. co.za/article.php?a_id=131615 (Geraadpleeg 2008.05.08). 
om nagenoeg 4300MW krag uit die skema in die Kongorivier te ontgin was reeds aan die einde van 2007 afgehandel. ${ }^{113}$ Projekte van hierdie aard is opgegee as een van die redes waarom Suid-Afrika nie summier kragvoorsiening aan buurlande kon opskort nie. Amptenare en kundiges het daarop gewys dat kragvoorsiening deel was van 'n poging tot groter samewerking tussen buurstate. Dit sou nie in die landsbelang wees om dienslewering op te skort nie. ${ }^{114}$ Terwyl kragstasies wat vroeër uitgeskakel is weer in gebruik geneem is, het Eskom bekend gemaak dat weer aan die ontwikkeling van kernkragsentrales aandag gegee sou word. Ook is oorweging geskenk aan windkragturbines wat in die afsienbare toekoms in die Wes-Kaap ingevoer sou word. ${ }^{115}$

\section{Politieke mentaliteit}

Die kragonderbreking en response oor die erns van die saak het op 'n verskeidenheid van maniere in die openbare sfeer van die Suid-Afrikaanse samelewing geregistreer. Dit het van meet af aan politieke ondertone gehad. Byvoorbeeld, binne 48 uur ná die eerste kragonderbreking op 18 Januarie, het meer as 2000 mense op 'n elektroniese argief van die werkverbond Solidariteit ten sterkste teen die kragonderbreking geprotesteer. ${ }^{116}$ Bykans in alle fasette van die samelewing het die regering onder skoot gekom. Die skyn van interne stabiliteit in die ANC wat voor die Polokwane-kongres van Desember 2007 bestaan het, was nie meer daar nie. 'n Nuwe demokratiese revolusie was aan die orde. Deel van hierdie denkstroom was om opnuut in ooreenstemming met bepaalde populistiese prioriteite in die belang van benadeelde mense politieke besluite te neem. Burgerlike ordelikheid was nie deel van hierdie mentaliteit nie. Die rede daarvoor was dat daar sommige kritici van die Mbeki-regering van mening was dat daar magsmisbruik deur 'n geselekteerde groepie mense aan die orde was. Hulle was daarop uit om hulself te verryk.

Opposisiepartye het die situasie uitgebuit en summier geëis dat die regering moes bedank. Daar is verduidelik dat dit 'n goeie begin sou wees as die verantwoordelike ministers en hoogsbesoldigde uitvoerende amptenare in die energiesektor, afgedank word. ${ }^{117}$ Daar was selfs oproepe in briewe in die koerante vir die partye om saam te staan teen die regering. ${ }^{118}$ Die ANC is daarop bedag gemaak dat die

113. C van der Merwe, "Construction of 4300MW hydropower project to start in next 18 to 24 months" in Engineering News, 2008.02.18 by http://www.engineeringnews.co.za/article.php?a_id=127200

114. Sapa, "Save electricity, or else" in Sowetan 2008.03.04 by http://www.sowetan.co.za/News/Article. aspx?id=719701 (Geraadpleeg 2008.05.02).

115. T Thakali, "What now for Eskom?”, in Pretoria News, 2008.02.23, p. 3 by http://www.iol.co.za/index. php?set_id=1\&click_id=3045\&art_id=vn20080223084338805C243450 (Geraadpleeg 2008.05.04); Eskom, "Eskom to secure funding for its wind farm project" Media release 29 February 2008 by http:/ / www.eskom. co.za/live/content.php?Item_ID=6084 (Geraadpleeg 2008.05.10).

116. Anon., "Want to tell Eskom what you think of them?” in Cape Times, 2008.01.23, p. 5. By http://www. iol.co.za/index.php?set_id=1\&click_id=3045\&art_id=vn20080123063445225C111252 $\overline{\text { (Geraadpleeg }}$ 2008.05.08); SAPA, "Power-cut stories flood website" in News 24, 2008.01.22 by http:/ /www.news24.com/ News24/South_Africa/Power_Crisis/0,2-7-2335_2262018,00.html (Geraadpleeg 2008.05.11).

117. W Misbach, "Parties want heads to roll over energy" in Sowetan, 2008.01.31 by http://www.sowetan.co.za/ News/Article.aspx?id $=695348$

118. Korrespondensie: K van der Walt, Winburg - Redakteur, "Staan nou saam" in Volksblad, 2008.02.06 by http://www.news24.com/Die_Volksblad/Briewe/0,5-89_2265894,00.html (Geraadpleeg 2008.05.08); C van Heerden - Redakteur, "Praat met ons kruisies" in Volksblad, 2008.01.29 by http://www.news24.com/ Die_Volksblad/Briewe/0,5-89_2260343,00.html (Geraadpleeg 2008.05.08); Korrespondensie: 'Funnybones' - Redakteur, "We should dissolve parliament" in News24, 2008.02.13 by http:/ / www.news24.com/News24/ MyNews24/Your_story/0,2-2127-2128_2269792,00.html (Geraadpleeg 2008.05.12). 
kultuur van boikot wat in die apartheidsera gekweek is, nou sy wrange vrugte begin dra. Die R4,4 biljoen in uitstaande rekenings wat aan stadsrade verskuldig was vir kragvoorsiening, is voorgehou as 'n voorbeeld van dié nalatenskap. ${ }^{119}$ Die werklike toedrag van sake was dat selfs al sou die regering van die dag bedank en 'n nuwe verkiesing uitskryf, was dit onwaarskynlik dat enige opposisieparty, of groepering van partye daartoe in staat sou wees om die bewind oor te neem. Hierdie wete het die frustrasievlakke van middelinkomste voorstedelike Suid-Afrikaners aansienlik verhoog.

Feit van die saak was dat die stille meerderheid van die land se mense swart Suid-Afrikaners was wat steeds daarvan oortuig was dat die ideale van die regerende party ook hulle persoonlike ideale verwoord het. In die swart media, wat deur bykans geen blankes gelees word nie, is mense aangemoedig om die regering in die krisis by te staan. Die Wêreldbeker Sokkerkompetiie van 2010 en die behoud van 'n ekonomie wat 'n inkomste vir die land se werksmag moes verseker, is voorgehou as redes waarom steun gegee moes word. In Sowetan is, in die vroeë fase van beurtkrag, steun toegesê aan 'n beroep wat die regering op SuidAfrikaners gemaak het, ${ }^{120}$ dat verbruikers hul kragverbruik met 20 persent verminder. ${ }^{121}$

Politieke kenners het geredeneer dat die mense vertroue in die land se hoof uitvoerende politieke leier, president Thabo Mbeki, verloor het. Die elektrisiteitskrisis kon sy swanesang wees. ${ }^{122}$ Mense na aan die president het ruiterlik erken dat segmente van die politieke leierskap, ná die bevryding van die land in die negentigerjare, uit voeling met die massas geraak het. Die huidige regering was nie daartoe in staat om die mense in die rigting van ' $\mathrm{n}$ bepaalde saak te mobiliseer nie. ${ }^{123}$

'n Belangrike simptoom van die toestand - ontevredenheid met swak dienslewering - het reeds 'n geruime tyd bestaan. Onafhanklike navorsers het daarteen gewaarsku. ${ }^{124}$ Byvoorbeeld, in die tydperk 2004-2005 het 900 onwettige en 6000 wettige protesbyeenkomste oor swak dienslewering in Suid-Afrika plaasgevind. ${ }^{125}$ Die vinger is veral gewys na die politieke bestuur van plaaslike owerhede. ${ }^{126}$

Namate dit duidelik geword het dat die kragonderbrekings nie die land se regering tot 'n val sou bring nie,

119. C Mdletshe, “'ANC to blame" in Sowetan, 2008.02.22 by http://www.sowetan.co.za/News/Article. aspx?id=711782 (Geraadpleeg 2008.05.02).

120. A Russel, "S Africa eyes rationing to end rolling power cuts" in Financial Times, 2008.01.24 by http://search. ft.com $/$ iai? referer $=$ http $\% 3 \mathrm{~A} \% 2 \mathrm{~F} \% 2$ Fsearch.ft.com $\% 2$ Fsearch $\% 3$ Fquery Text $\% 3$ Delectricity $\% 2 \mathrm{Band} \% 2 \mathrm{Bs}$ outh $\% 2 \mathrm{Bafrica} \% 26 \mathrm{aje} \% 3 \mathrm{D}$ true $\% 26 \mathrm{dse} \% 3 \mathrm{D} \% 26 \mathrm{dsz} \% 3 \mathrm{D} \& \mathrm{page}=2$ \&query $T$ Text $=$ electricity + and + south + af rica\&location $=\mathrm{http} \% 3 \mathrm{~A} \% 2 \mathrm{~F} \% 2 \mathrm{Fsearch} . \mathrm{ft} . \mathrm{com} \% 2 \mathrm{FftArticle} \% 3 \mathrm{Fquery}$ Text $\% 3$ Delectricity $\% 2 \mathrm{Band} \% 2 \mathrm{Bsou}$ th $\% 2$ Bafrica $\% 26 a j e \% 3$ Dtrue $\% 26 i d \% 3$ D $080124000301 \% 26 \mathrm{ct}^{\%} \% 3 \mathrm{D} 0 \% 26 \mathrm{page}^{\circ} \% 3 \mathrm{D} 2 \&$ aje $=$ true\&ct $=0 \& \mathrm{kid}=$ 080124000301

121. Editorial comment: "Shabby way to treat the nation" in Sowetan, 2008.01.31 by http://www.sowetan.co.za/ Feedback/Article.aspx?id=695490 (Geraadpleeg 2008.02.03)

122. P Laurence, "President is major casualty of power crisis" in The Sunday Independent, 2008.02.03, p. 8.

123. N Makgetla, "Too many left out of search for power solutions" in Business Day, 2007=8.02.06 by http:// www.businessday.co.za/articles/topstories.aspx?ID=BD4A699637.

124. Anon., "Voices of anger: Phumelela and Khutsong: protest and conflict in two municipalities," in CDE Focus, 10, April 2007 (Occasional papers reflecting continuing research produced for the Centre for Development and Enterprise, Johannesburg, 2007), pp. 1-18.

125. P Laurence, "President is major casualty of power crisis" in The Sunday Independent, 2008.02.03, p. 8.

126. Editorial comment: "Immoral council" in Sowetan, 2008.01.30 by http://www.sowetan.co.za/Feedback/ Article aspx?id=694344 
het die leier van die Demokratiese Alliansie (DA), me Helen Zille, met die staatspresident onderhandel en sekere voorstelle gemaak oor die wyse waarop die krisis aangespreek kon word. ${ }^{127}$ Ironies genoeg het haar provinsiale tuiste, die Wes-Kaap, kort ná die samesprekinge, grootskaalse kragonderbrekings in die gesig gestaar. ${ }^{128}$

'n Belangrike les wat politici uit die krisis geleer het, was dat dit noodsaaklik was om die waarheid te praat - wanneer dit gegaan het oor 'n saak wat al die land se mense regstreeks raak. Daar kon nie doekies omgedraai word nie. Me Bujelwa Sonjica, die minister van energie en minerale, is by geleentheid deur die media voor stok gekry nadat sy in die parlement gesê het Suid-Afrikaners behoort die kragonderbrekings produktief te gebruik om vroeg te gaan en slaap en slimmer te word. Haar uitspraak was onmiddellik in 'n politieke stofwolk gehul. Daarna het sy verklaar dat wat in die parlement eintlik gebeur het, was dat sy, terwyl sy haar toespraak gemaak het, in die rede geval is deur mnr Tony Leon van die DA. In respons op sy tussenwerpsels het sy die gewaande woorde gespreek, het me Sonjica tydens 'n radio-onderhoud verduidelik. ${ }^{129}$ Die saak is nie daar gelaat die. Verslaggewers het ondersoek ingestel en vasgestel dat daar in Hansard-beriggewing oor die betrokke debat, geen bewyse was dat Leon haar tydens haar toespraak in die rede geval het nie. ${ }^{130}$ Sonjica het, soos haar kabinetskollega, mnr Eric Erwin, ${ }^{131}$ geleer dat tydens 'n elektrisiteitskrisis is dit noodsaaklik om 'n reguit paadjie met die verbruikerspubliek te loop.

In 'n week waarin die parlement die president se rede intensief bespreek het, was die hoogtepunt 'n mosie van wantroue in die staatspresident en die regering van al die land se opposisiepartye. Die president se respons was dat die land se mense eerder moes begin om die positiewe kant van dinge te sien en te besef dat pessimisme niemand êrens gaan bring nie. Hy het in goeie Afrikaans verduidelik "'n Boer maak 'n plan". ${ }^{132}$ 'n Mosie van wantroue in de regering, het weens die getallevoordeel van die ANC in die parlement, nie geslaag nie.

'n Aspek van regeringsbeleid wat tydens die krisis die meeste onder skoot gekom het, was swart ekonomiese bemagtiging. Kritiek op die regering en Eskom tydens die krisis het van meet af aan gewentel om effektiewe dienslewering en die instandhouding van infrastruktuur. Die historiese rekord van prestasies van swart ekonomiese bemagtiging was veral onder die soeklig. Die grootste kritiek was vanuit blanke geledere. Duisende blankes, veral geskoolde en gespesialiseerde amptenare, het vanaf 1994 die staatsdiens verlaat. 'n Magdom redes het bestaan vir hulle vertrek, maar die belangrikste daarvan was dat hulle benadeel in die werkplek gevoel het. Eskom was een van die semi-staatsinstellings wat die beleid van swart ekonomiese bemagtiging nougeset nagestreef het. Kritici was van mening dat hulle voorspellings waar geword het

127. Sapa, Mbeki, Zille in heart-to-heart talks" in Sowetan, 2008.01.28. by http://www.sowetan.co.za/News/ Article. aspx?id=693635

128. Eskom, Media release 1 February 2008 by http://www.eskom.co.za/live/content.php?Item_ID=5800 (Geraadpleeg 2008.05.10).

129. Mededeling me Sonjica, tydens onderhoud op Classic Business, Classic FM 102.7. Kort ná 18:00 op 2008.02.05.

130. J Gordin and L Flanagan, "Hansard drops Sonjica in the dwang" in Independent Online by http:/ / www.iol.co.za/ index.php?set_id=1\&click_id=3045\&art_id=vn20080210084225761C897104 (Nagegaan 2008.02.15)

131. W Jordaan, “G'n sabotasie by Koeberg, erken Erwin” in Beeld, 2006.08.17 by http://www.news24.com/ Beeld/Suid-Afrika/0,3-975_1984698,00.html (Geraadpleeg 2008.05.20); W Pelser, “Koeberg-verdagtes geëien”" in Beeld, 2006.03.02 by http://www.news24.com/Beeld/Suid-Afrika/0,33-975_1891328,00.html (Geraadpleeg 2008.05.20).

132. J de Lange, "Hou op kla - Mbeki” in Beeld, 2008.02.15, p. 1. 
toe Eskom se beleid teen April 2008 aangepas is om voorsiening te maak vir die herindiensneming van nagenoeg 300 blanke tegnici om probleme met kraglewering te help uitwis. ${ }^{133}$ Ook buitelandse kundiges is op grootskaal gewerf. Op die blog van 'n Sondagkoerant het hierdie stap 'n kritiese respons van lesers, uit alle wêrelddele gelok. ${ }^{134}$ Swartbemagtiging het verder in die spervuur van kritiek beland nadat die prys van steenkool verhoog is. In die betrokke tyd het dit aan die lig gekom dat Eskom 'n groot aantal swartbemagtigingsinstansies gebruik het om steenkool te voorsien. ${ }^{135}$ Vreemde verhale het in die pers uitgekom. Daar was swartbemagtigingsmaatskappye letterlik op plase in Mpumalanga, sonder toestemming, met kruiwa en graaf steenkool gemyn het. ${ }^{136}$ Kritici van swartbemagtiging het dit ten sterkste veroordeel.

Mense wat oor die kragkrisis kommentaar gelewer het, het beklemtoon dat hulle nie rassistiese oogmerke het nie. ${ }^{137}$ Daar was egter ook dié wat aangevoer het dat die elektritisiteitskrisis wel gevoelens van rassisme sou aanwakker. ${ }^{138}$ 'n Ingenieur het suggesties van rasgebaseerde ondoeltreffendheid as 'irrelevant' afgemaak. In die besonder het hy verwys na die minister, Alec Irwin, wat duidelik nie daartoe in staat was om die krisis van kragonderbrekings behoorlik te verstaan en bestuur nie. ${ }^{139}$ 'n Eskom-advertensieveldtog om gebruikers meer sensitief te maak vir die krisis, het onder fel kritiek deurgeloop. Kundiges het gereken dat vals voorstellings gemaak is en elemente daarvan het rassistiese stereotipes uitgebuit. ${ }^{140}$

Suid-Afrikaners op voetsoolvlak, het van meet af aan ook nouliks tussen die regering en Eskom onderskei. ${ }^{141}$ Die statuur van die regering - in die besonder die kabinet - is die nadeligste geraak. ' $\mathrm{n}$ Uitstaande kenmerk was dat Eskom op 'n bepaalde manier op 'n krisis in die voorsieningsproses sou reageer. ${ }^{142}$ Die regering sou òf daarmee saamstem, of 'n geringe verandering aan die hand doen. ${ }^{143}$ Kort daarna sou die ANC as party ook op die krisis reageer en 'n heeltemal ander standpunt inneem. ${ }^{144}$

133. S Ngalwa, "Load-shedding backfires on Eskom" in The Sunday Independent, 2008.04.27, p. 3.

134. L Steenkamp, "Eskom-noodkreet” in Rapport, 2008.04.27, p. 1.

135. Korrespondensie: T Aspeling - Redakteur, "Paying for Eskom collusion" in News24, 2008.04.08 by http:// www.news24.com/News24/MyNews24/Your_story/0,2-2127-2128_2301954,00.html (Geraadpleeg 2008.05.10).

136. Anon., "Eskom whistles in the dark" in Noseweek, 103, May 2008, p. 10.

137. Korresponedensie: D Wolpert, Rivonia - Redakteur, "New ineptness" in Business Day, 2008.02.13 by http:// www.businessday.co.za/articles/article.aspx?ID=BD4A704992 (Geraadpleeg 2008.05.01).

138. Korrespondensie: I Bergh, Marchand - Redakteur, "Rassisme hier om te bly" in Volkslad, 2008.04.09 by http://www.news24.com/Die_Volksblad/Briewe/0,5-89_2303206,00.html (Geraadpleeg 2008.05.08).

139. Korrespondensie: G Carter, Wierda Park - Redakteur, "Beyond race lines" in Business Day, 2008.03.20 by http://www.businessday.co.za/articles/article.aspx?ID=BD4A730850 (Geraadpleeg 2008.04.29).

140. A Butler, "How Eskom, state indecision plunged SA into darkness" in Business Day, 2008.03.03 by http:// www.businessday.co.za/articles/topstories.aspx?ID=BD4A718702 (Geraadpleeg 2008.05.01); P Mann, "Eskom must manage outrage as well as outages in Business Day, 2008.03.11 by http://www.businessday. co.za/articles/topstories.aspx?ID=BD4A725158 (Geraadpleeg 2008.04.29); Korrespondensie: Geskok, Bloemfontein - Redakteur, "Eskom skok met morsery" in Volksblad, 2008.04.04 by http://www.news24. com/Die_Volksblad/Briewe/0,5-89_2299719,00.html (Geraadpleeg 2008.05.07).

141. Anon., "Gauteng hit most by blackouts" in News24 2008.03 .18 by http://www.news24.com/News24/ South_Africa/Power_Crisis/0,2-7-2335_2290289,00.html (Geraadpleeg 2008.05.10).

142.SAPA, "It's a crisis"” in News24, 2008.01.20 by http://www.news24.com/News24/South_Africa/ Politics/0,2-7-12_2256435,00.html (Geraadpleeg op 2008.05.11).

143. Anon., "Government support 53\% hike” in News 24, 2008.03 .19 by http://www.news24.com/News24/ South_Africa/Power_Crisis/0,2-7-2335_2291351,00.html (Geraadpleeg op 2008.05.12).

144. Anon., "Disaster waiting to happen" in News24, 2008.05.02 by http://www.news24.com/News24/South Africa/Power_Crisis/0,2-7-2335_2315408,00.html (Geraadpleeg 2008.05.10). 
Hierdie tipe van respons het die indruk geskep dat die regering (die kabinet) en Eskom besig was om saam te werk. In gevalle waar die ANC as party gereageer het op aankondigings, wou dit voorkom asof die kabinet en Eskom in besluitnemingsprosesse teengestaan is. Die rede vir hierdie toedrag van sake is toegeskryf aan die historiese ontwikkeling van die kragvoorsieningsbedryf in Suid-Afrika. In 1987 het die voormalige NP-regering die Eskomwet deurgevoer. Die doel daarmee was om te verseker dat Eskom in infrastruktuur belê. In ruil daarvoor was die kragvoorsiener nie meer belastingpligtig nie. ${ }^{145}$ In 1998 is die Eskomwysigingswet, 128 van 1998 deurgevoer. Die onderneming is nou in 'n maatskappy met net een aandeelhouer - die staat - omskep. Daarna is die Eskom Conversion Act, 13 van 2001 goedgekeur. ${ }^{147}$ As 'n openbare onderneming was Eskom steeds, soos sedert 1998, belastingpligtig en onderhewig aan die uitbetaling van dividende aan die staat. ${ }^{148}$

Die onderliggende politieke mentaliteit was een waarin die regerende party se leierskap daadwerklik daarvan bewus gemaak is dat intense infrastrukturele probleme in dienslewering aan die orde van die dag was. Daar is egter verwag van die burgerlike bevolking om dapper voort te gaan en struikelblokke die hoof te bied. Die opposisiepartye het onbewustelik daarvan bewys gelewer dat hulle in 'n bepaalde toestand van politieke realiteitsbesef verkeer het: hulle sou nie daartoe in staat wees, selfs as 'n verkiesing uitgevaardig word, om die mag in Suid-Afrika oor te neem nie. Hierdie gevoel het bloot tot gevolg gehad dat met kritiek volgehou is. 'n Strategie van hoe hulle te werk sou gaan om byvoorbeeld as 'n koalisie van partye, die regering te bedryf, het nie bestaan nie. Met ander woorde, die opposisie het magteloos gevoel, en dienooreenkomstig gefunksioneer. In die politieke diskoers wat rondom die elektrisiteitskrisis gevoer is, was dit duidelik dat daar nie plek vir arrogansie was nie. Die publiek het van die politieke leierskap verwag om die probleem aan te spreek. Die feit dat magsverskuiwings in die regering aan die orde was, het' $n$ groter bereidwilligheid laat posvat om samesprekings te voer sodat planne gemaak kon word oor die wyse waarop die krisis aangespreek kon word. In die media is die moontlikheid van samewerking tussen die twee vleuels van die ANC (dié in die kabinet, en dié wat in 2009 die bewind sou oorneem) sterk in twyfel getrek. ${ }^{149}$

\section{Ekonomiese mentaliteit}

In die ekonomiese milieu het die elektrisiteitskrisis van 2008 veral op twee terreine besonder sterk na vore gekom. Eerstens het dit gegaan oor produksie in die mynbousektor. Dié was aan bande gelê. Tweedens het dit gegaan oor die moontlikheid dat grootskeepse werkloosheid, indien onderbrekings moes voortduur. Veral buitelandse beleggers en ondernemings wat aangewese was op Suid-Afrikaanse minerale, het die ontluikende krisissituasie nougeset dopgehou. ${ }^{150}$ Sprekend van die krisis was die feit dat die prys van

145. Anon., "Eskom whistles in the dark" in Noseweek, 103, May 2008, p. 7.

146. Kennisgewing 1669, Kantoor van die staatspresident, 18 Desember 1998 in Staatskoerant van die Republiek van Suid-Afrika, Nr 19617, 2008.12.18, pp. 1-6.

147. Notice 721, Office of the Presidencey, 3 August 2001, in Government Gazette of the Republic of South Africa, No. 22545, 2001.08.03, pp. 2-5.

148. Anon., "Eskom whistles in the dark" in Noseweek, 103, May 2008, p. 7.

149. Redaksionele kommentaar, "REDS nou solution to power problem" in Business Day, 2008.04 .28 by http:// www.businessday.co.za/articles/topstories.aspx?ID=BD4A752677 (Geraadspleeg 2008.04.28).

150. M Klein, "London reassurance” in Sowetan, 2008.02.21 by http:/ /www.sowetan.co.za/News/SpecialReports/ Budget2008/Article.aspx?id=710684 (Geraadpleeg 2008.05.02). 
veral goud en platinum die hoogte in geskiet het. Desondanks was die vooruitsig van werkloosheid 'n wesentlike vrees by baie Suid-Afrikaners. ${ }^{151}$

Die kragkrisis het, bykans onmiddellik in die handelsektor geregistreer. Reeds voor die einde van Januarie 2008, was daar berigte van groot verliese wat in winkelsentrums gely is. ${ }^{152}$ Die implikasies van korter handelsure en onderbrekings in dienslewering het vinnig ingesink. ${ }^{153}$ Teen April het huurders van kommersiële persele eienaars versoek om huurgeld te verlaag. Beurtkrag was besig om hul handelsgeleenthede te raak. Dit het bepaalde implikasies vir die inkopiesentra ingehou. Die kleinhuurders was vir die eiendomsmaatskappy van besondere waarde. Hulle het hoër huurgeld betaal as kettingwinkelgroepe. ${ }^{154}$ Die kleinsakeondernemings was nou uitgelewer en die eienaars van inkopiesentra moes opnuut besin oor hulle huurders en moontlike toegewings wat gemaak kon word.

In sommige handelsektore was daar goeie besigheid. In die vroeë fase van kragonderbrekings was veral sonligverwarmingstelsels vir huishoudelike water, teen sowat R20 000 per eenheid, in groot aanvraag. Die regering was vinnig om kennis te neem van die wyse waarop die Chinese ekonomie en kragvoorsieningsinfrastruktuur baat gevind het by die infasering van sonpanele vir warmwatervoorsiening. ${ }^{155}$ Plaaslike ondernemers - veral in die loodgietersbedryf - het ook begin om van die nuwe tegnologie kennis te neem. Daar was ook oorywerige kleinhandelaars wat oordeelsfoute gemaak het. Teen Mei 2008 was dit duidelik dat nie alle verbruikers deur paniekaankope op sleeptou geneem is nie. By een van die land se groot hardeware winkelgroepe is is die prys van petrolkragopwekkers met 20 per sent verlaag nadat die vraag na dié toerusting vinnig afgeneem het. ${ }^{156}$

Van meet af aan was dit duidelik dat verbruikers sou moes betaal om die land se kragvoorsiener te help. In die jaarlikse begroting het die regering aangekondig dat dit sowat R60 biljoen aan Eskom die volgende vyf jaar sou gee. Van verbruikers is verwag om 2 sent in die vorm van belasting te betaal vir elke Kilowattuur wat krag gebruik is. ${ }^{157}$ Daaroor was baie ongelukkigheid. Dit het belastingskwessies na vore gebring. Joffre Papenfus het in 'n brief aan 'n koerant aangevoer dat belastingbetalers moes verenig en weier om belasting te betaal. Trouens, daar moes eintlik 'n rabat van 100 persent aan hulle terugbetaal moet

151. N Mawson, "Electricity crisis may affect job market in Business Day, 2008.03.28 by http://www.businessday. co.za/articles/topstories.aspx?ID=BD4A726149 (Geraadpleeg 2008.04.29); Staff reporter, "7000 jobs at risk" in Sowetan, 2008.02.26 by http://www.sowetan.co.za/News/Article.aspx?id=713944 (Geraadpleeg, 2008.05.02).

152. S Piliso en S Govender, "Eskom pulls the plug on Southern Africa" in The Times, 2008.01.19 by http://www. thetimes.co.za/News/Article.aspx?id=685437 (Geraadpleeg 2008.05.01).

153. L Paulsson, "Investment crucial for power generation" in Business Day, 2008.04.19 by http:/ / www.businessday. co.za/weekender/article.aspx?ID=BD4A751879 (Geraadpleeg 2008.04.28).

154. Property editor, "Power cuts 'to hit listed retail property firms"' in Business Day, 2008.04.11 by http://www. businessday.co.za/articles/topstories.aspx?ID=BD4A746312 (Geraadpleeg 2008.04.28).

155. Dr. Xiaodong Wang (World Bank), “Technical Assistance for Energy Efficiency in South Africa”, PowerPoint presentation Government Workshop, Sandton, 2008.02.11.

156. V de Klerk, "Retailers still feel Eskom blues" in News24, 2008.05.05 by http://www.news24.com/News24/ South_Africa/Power_Crisis/0,2-7-2335_2316870,00.html (Geraadpleeg 2008.05.10).

157. J Avni en Z Mokgata, "Consumers to pay more for energy" in Sowetan, 2008.02.21 by http://www.sowetan. co.za/News/SpecialReports/Budget2008/Article.aspx?id=710767 (Geraadpleeg 2008.05.02). 
word, in maandelikse paaiemente vir die skade wat gely is tydens kragonderbrekings. ${ }^{158}$ Die regering het ook genoem dat krag in die toekoms duurder sou word. ${ }^{159}$ Briefskrywers aan koerante het gevolglik verbruikers aangeraai om kritiese vrae te stel oor uitermatige kragtariewe wat hulle aan plaaslike owerhede moes betaal. ${ }^{160}$ Daar was twyfel in die vermoë van die plaaslike en sentrale regering om oordeelkundig die krisis te bestuur.

Kort nadat die kragkrisis in Januarie 2008 begin het, het die regering en sakeleiers hande gevat. Op 8 Februarie, by geleentheid van sy openingsrede van die nuwe jaar se parlementsitting, het pres. Mbeki verduidelik dat hy daarvan bewus was dat baie mense in die samelewing 'n diepgesetelde gevoel van ongemak gekoester het. Hy het wel die versekering gegee dat die krisis intensief ondersoek word en dat nywerheidsleiers van oordeel was dat die situasie nie 'n ramp verteenwoordig het nie. Dit kon wel opgelos word. ${ }^{161}$ Dit het gevolg op samesprekinge wat vroeër tussen 131 van die land se topbestuurders van 38 groot maatskappye met die regering gevoer is. Die boodskap wat by die publiek tuisgebring is, het daarop gedui dat die regering, in samewerking met die privaatsektor, alles in werking sou stel om die krisis aan te spreek. ${ }^{162}$ Opvolggesprekke het plaasgevind en dit was spoedig duidelik dat konstruktiewe planne aan die hand gedoen is. ${ }^{163}$

Insette deur die sakeleiers en verteenwoordigers van die Wêreldbank, Eskom het bepaald daartoe meegewerk dat korporatiewe stresvlakke vlakke aansienlik verlaag is. ${ }^{164}$ Dit wou voorkom asof sakelui die regering wou bystaan. In sakenuus is selfs verklaar dat kritiek teen die regering se hantering van die elektrisiteitskrisis ongegrond was. ${ }^{165}$ Die groot voordeel van samewerking was dat die sakelui 'n indrukwekkende arsenaal van navorsingsdeskundigheid kon inspan om proaktief op die elektrisiteitskrisis te fokus. Byvoorbeeld, navorsers van Avior het die voorbeeld van die Brasiliaanse kragkrisis in 2001 gebruik en 'n futuristiese beeld van verwagte tendense in die kleinhandel weergegee. Onder meer is bevind dat daar 'n afname in verbruikersvertroue gaan wees. Verbruikers sou straks minder nie-noodsaaklike goed begin koop. Ook kraggedrewe goedere sou minder geredelik gekoop word. Daar sou eerder na alternatiewe opsies gekyk word. Mense sou begin om eerder gaslampe en stowe te koop. Dit sou moontlik wees dat verbruikers kleiner hoeveelhede goed begin koop deurdat hulle nie bederfbare goedere in grootmaat wou hou nie. Donker winkelsentrums was sleg vir besigheid. Kruidenierwinkels moes daarop bedag wees dat hulle met

158. J Papenfus, Pretoria - Redakteur, "Demand a rebate" in Business Day, 2008.02.06 by http:/ / www.businessday. co.za/articles/opinion.aspx?ID=BD4A699743

159. J Avni, "High power bills coming: electricity users to dig deeper into their pockets in next five years" in Sowetan, 2008.02.22 by http:/ / www.sowetan.co.za/News/Article.aspx?id=711748 (Geraadpleeg 2008.05.02).

160. H Boesenberg, Monumentpark - Redakteur, "Wat kos elektrisiteit in jou area?" in Beeld, 2008.02.19, by http://www.news24.com/Beeld/Opinie/Briewe/0,3-2085-73_2273640,00.html

161. M\&G reporter and Sapa, "We shall overcome, says Mbeki” in Mail \& Guardian, 2008.02.08 by http://www. mg.co.za/articlePage.aspx?articleid $=331814 \&$ area=/breaking_news $/$ breaking_news_national/ (Geraadpleeg op 2008.02.15.)

162. J Visser, "Eskom, sakelui vorm taakspan teen kragkrisis" in Sake-Beeld, 2008.01.22 by http://152.111.1.251/ argief/berigte/beeld/2008/01/22/B1/1/jvEskom.html

163. Mediaverklaring, "Presidential joint working group on electricity" by The Presidency Republic of South Africa, 2008.02.28 at http://www.thepresidency.gov.za/main.asp?include=president/pr/2008/pr0229842.htm

164. Kyk o.m. PP-aanbiedings wat by die geleentheid aangebied is. Bulk procurement of Energy-Efficient Equipment; South Africa. Energy Efficiency Policies and Institutional Arrangements; Managing Capacity and Energy Shortfalls - Experience from California; Institutional Arrangements for Energy Efficiency; L Maurer, Implementing power rationing in a sensible way: lessons learned and international best practices.

165. J de Lange, "Los kleinsieligheid oor Eskom” in SakeBeeld, 2009.02.19 by http:/ /152.111.1.251/argief/berigte/ beeld/2008/02/19/B1/12/JanSakesiening.html 
groter hoeveelhede bederfbare goedere opgeskeep sou wees. ${ }^{166}$ Ofskoon baie sakemense die regering lees die kabinet - goedgesind was, en moontlik wou help, het dieselfde houding nie teenoor Eskom, die kragvoorsiener, gegeld nie.

Die kragkrisis het die ekonomie regstreeks geraak. In die eerste drie maande van 2008 het sakevertroue in die land se vervaardigingsektor, volgens die Buro vir Ekonomiese Navorsing, tot vlakke gedaal wat laas in 2003 geregistreer is. ${ }^{167}$ In die media is die openbare ondernemingsminister, Eric Erwin, gekritiseer nadat hy verklaar het dat Suid-Afrika 'n jaarlikse groeikoers van tussen 4 en 5 persent sou kon volhou tot 2010 wanneer die sokkerwêreldbeker aangebied word. ${ }^{168}$ Sakelui het prontuit verklaar dat swak bestuur by Eskom die oorsaak van die krisis was. ${ }^{169}$ Een briefskrywer aan die pers, Dr Lucas Ntyintanyane, het Eskom se bestuur gekritiseer vir die nastrewing van middelmatigheid. Uitnemendheid, was nie meer relevant nie in 'n omgewing wat paradoksale waardesisteme gelate aanvaar het. ${ }^{170}$ Sakelui het ook dat Eskom nie geweet hoe om op krisisomstandighede te reageer nie. Die kragvoorsiener het hom beroep op 'n bestuurstrategie, bekend as vraagkantbestuur (in Engels: demand side management [DSM]). Hierdie is ' $n$ strategiese bestuursintervensie wat in die 1980s in die Verenigde State van Amerika ingevoer is. In Suid-Afrika is vir die eerste keer in 1992 van die strategie gebruik gemaak. ${ }^{171}$ Daar bestaan rede om te glo dat die besluit wat in 1997 geneem is om nie verdere uitbreidings aan die infrastruktuur van Eskom aan te bring nie, waarskynlik deur hierdie beleid beïnvloed is. Bestuurslui in die vervaardigingen handelsektor was vinnig om die vraagkantbestuurstrategie van Eskom te kritiseer. Dit was veral ná groot tariefverhogings (53 persent) deur Eskom op 18 Maart 2008 voorgestel is. ${ }^{172}$ Die pessimisme van sommige sakeleiers het duidelik 'n invloed op die publiek gehad. Eskom was duidelik nie daartoe in staat om met die privaatsektor om die hart en siel van die publiek mee te ding nie. Die gevolg was dat voortgesette gerugte van 'n klaarblyklike gebrek aan 'n gepaste bestuurstrategie, die aansien van die kragvoorsiener nadelig getref het. ${ }^{173}$

Intussen het onenigheid tussen die leiers van die ANC en die land se regering, invloedryke mense in die sakewêreld ook regstreeks beïnvloed. Veral op die terrein van tariefverhogings - 'n materiële saak wat die besigheidswêreld regstreeks aangestaan het - is die gebrek aan eenheid in die regering as 'n swakheid

166. N brand, "SA kan lesse leer uit Brasiliaanse kragkrisis - navorsingsgroep" in SakeBeeld, 2008.02.19, p. B1 by http://152.111.1.251/argief/berigte/beeld/2008/02/19/B1/1/nbretail_1342.html

167. M Isa, "Hope for exports even as output dips" in Business Day, 2008.03.18 by http:/ /www.businessday.co.za/ articles/topstories.aspx?ID=BD4A729268 (Geraadpleeg 2008.04.29).

168. K Seekoei, "Economic myth grows as power demand recedes" in Sowetan, 2008.01.30.

169. A Butler, "How Eskom, state indecision plunged SA into darkness" in Business Day, 2008.03.03 by http:// www.businessday.co.za/articles/topstories.aspx?ID=BD4A718702 (Geraadpleeg 2008.05.01).

170. Korrespondensie: Dr. L Ntyintyane, Cresta - Redakteur, "Strive for better" in Business Day, 2008.03.31 by http://www.businessday.co.za/articles/article.aspx?ID=BD4A736997 (Geraadpleeg 2008.04.29).

171. Eskom, “About...” by http://www.eskom.co.za/live/content.php?Category_ID=25 (Geraadpleeg 2008.0510).

172. Anon., "Eskom wants 535 tariff hike" in News24, 2008.03.18 by http://www.news24.com/News24/South_ Africa/Power_Crisis/0,2-7-2335_2290470,00.html (Geraadpleeg 2008.05.12).

173. 'n Soortgelyke strategie (watervraagbestuur) is deur Rand Water, tydens die ernstige droogtetydperk van die 1980's nagevolg. Ofskoon die beleid aanvanklik met welslae toegepas is, het dit tot grootskeepse verbruikersweerstand aanleiding gegee namate daar sprake was van 'n kunsmatige verlenging van beperkings. Kyk JWN Tempelhoff, "From water restrictions to water demand management: Rand Water and water shortages on the South African landscape (1983-2003)" in PS Juuti, TS Katko and HS Vuorinen (eds.), Environmental history of water - global views on community water supply and sanitation, (IWA Publishing, London, 2007), pp. 531-562. 
gesien wat aangeval kon word. ${ }^{174}$ Leierskap is in twyfel getrek. Dit het algemene kennis geword dat selfs die openbare beskermer $(\mathrm{OB})$ wat ondersoek na die kragkrisis ingestel het, het tou opgegooi nadat 'n parlementêre ondersoek na die krisis min lig op die elektrisiteitskrisis kon werp. ${ }^{175}$ Tussendeur is die bestuurslui van Eskom deur die kommunikasiekundige Peter Mann, aangeraai om regstreeks beheer van die krisis te probeer neem. Ferm leierskap was nodig. Hulle moes minder arrogant wees. Die publiek moes nie onverwags sonder krag gelaat word nie. Inligting moes doeltreffend en deurlopend bestuur word, sonder dat ' $\mathrm{n}$ enkele woordvoerder vir al die onderneming se foute verantwoording doen. ${ }^{176}$ Ondanks waarskuwings dat dit noodsaaklik was om akkuraat inligting aan die publiek deur te gee oor wanneer en waar beurtkrag sou plaasvind, het Eskom dit nie altyd gedoen nie. Soms is groot foute gemaak en elektroniese regstellings het wantroue by die publiek geskep. ${ }^{177}$ 'n Voorbeeld van hierdie wantroue was die feit dat selfs toe daar aan die einde van April 2008 bekend gemaak is dat beurtkrag opgeskort is, was daar woordvoerders van plaaslike owerhede wat nie eens daarvan bewus was nie. ${ }^{178}$

Die ontevredenheid van mense met die kommunikasie van Eskom is duidelik weerspieël in hul onwilligheid om 'Eskom-taal' te aanvaar. In die gewone omgang is die term 'beurtkrag', bekend as 'load shedding' in Engels, wat deur Eskom ingevoer is, summier verwerp. ${ }^{179}$ Daar is verduidelik dat dit 'n 'spindoctered'poging was om 'n alternatiewe naam vir eenvoudige kragonderbrekings te gee. ${ }^{180}$ Vir Hillary Joffe was dit 'serial load shedding', 'outage slippage' en 'load losses' wat eintlik net beter lig op 'system recovery process' en 'n 'power conservation programme' gewerp het. ${ }^{181}$ Ironies is die feit dat die gebruik van eufemistiese terminologie om kragonderbrekings te beskryf, reeds aan die begin van Januarie 2008 ten sterkste deur kundiges afgeraai is. ${ }^{182}$ Die bestuur van Eskom het hulle klaarblyklik nie aan die advies gesteur nie.

Tydens die elektrisiteitskrisis het ontwikkelingsinisiatiewe van die regering ook onder skoot gekom. Die wenslikheid van die beplande aluminiumsmelter van Rio Tinto Alcan by Koega, naby Port Elizabeth, is reeds vroeg in die era van kragonderbrekings bevraagteken. ${ }^{183}$ Die projek het ten doel gehad om

174. Anon., "Editors query Eskom 'secrets"” in News24, 2008.04.09 by http://www.news24.com/News24/South_ Africa/Power_Crisis/0,2-7-2335_2303033,00.html (Geraadpleeg 2008.05.10).

175. W Johwa, "Public protector probes reveal few answers" in Business Day, 2008.02.15 by http:/ / www.businessday. co.za/articles/article.aspx?ID=BD4A706885 (Geraadpleg 2008.05.01).

176. P Mann, "Eskom must manage outrage as well as outages in Business Day, 2008.03.11 by http://www. businessday.co.za/articles/topstories.aspx?ID=BD4A725158 (Geraadpleeg 2008.04.29).

177. Anon, "Matter will corrode before Telkom gives up the loop" in Business Day, 2008.03.04 by http://www. businessday.co.za/articles/article.aspx?ID=BD4A719399 (Geraadpleeg 2008.04.29); Korrespondensie: J Venter, Pellissier - Redakteur, "Waarom so agterbaks?” in Volksblad, 2008.03.19 by http:/ /www.news24.com/ Die_Volksblad/Briewe/0,5-89_2290674,00.html (Geraadpleeg 2008.05.08).

178. N Mfusi, "Sigh of relief over end to blackouts" in The Mercury, 2008.05.02, p. 3 by http:/ /www.iol.co.za/index. php?set_id=1\&click_id=3053\&art_id=vn20080502081246977C808193 (Geraadpleeg 2008.05.04).

179. T Molefe, "The candle generation may now shed a lot of fun" in Sowetan, 2008.01.24 by http:/ / www.sowetan. co.za/Columnists/ThembaMolefe/Article.aspx?id=690485 (Geraadpleeg 2008.03.05).

180. N Moreosele, "Load shedding ignites creative naming frenzy" in Sowetan, 2008.01.29 by http://www.sowetan. co.za/Columnists/AndrewMolefe/Article.aspx?id=693394

181. H Joffe, "Size of the problem will depend on nature of our solutions" in Business Day, 2008.02.06. by http:// www.businessday.co.za/articles/topstories.aspx?ID=BD4A699628

182. Anon., "Call a blackout a blackout!" in Energy crisis - South Africa, 2007.12.13 by http://energycrisis. co.za/?p=3 (Geraadpleeg 2008.05.10).

183. Reuters, "Eskom to review Coega deal" in Sowetan, 2008.01.31 by http://www.sowetan.co.za/News/Article. aspx?id=695346 (nagegaan 2008.02.03). 
ekonomiese ontwikkeling in die Oos-Kaap te bevorder. Vroeër het die voorgenome projek onder skoot van omgewingsbewustes en ingenieurs gekom. Daar is gewaarsku dat die smeltery'n energie-intensiewe bedryf was wat ' $n$ omgewingsonvriendelike ontwikkeling op die Suid-Afrikaanse platteland sou toelaat. Die produksie was ook grootliks vir buitelandse markte bestem. Die fabriek sou nagenoeg $1355 \mathrm{MW}$ elektriese krag - sowat 4 per sent van die totale kapasiteit van die land - benodig om in bedryf te bly. ${ }^{184}$ Teen Februarie 2008 was die aanduidings dat die Koega projek sou voortgaan. Die staat wou graag buitelandse beleggers trek met die vooruitsig van goedkoop elektrisiteitstariewe. ${ }^{185}$ Daar is selfs gepoog om die publiek te paai deur bekend te maak dat 'n biobrandstof-aanleg ook by Koega opgerig sou word. ${ }^{186}$ Tussendeur is voortgegaan om die Koega-projek te gebruik om beleggerskapitaal na SuidAfrika te lok. ${ }^{187}$ Plaaslike sakelui het egter voet by stuk gehou dat die beplande ontwikkelingsprojek in die toekoms die wind van voor sou kry. ${ }^{188}$

'n Voordelige ontwikkeling tydens die elektrisiteitskrisis was dat 'n ou debat, oor die privatisering van kragdienslewering, nuwe lewe gekry het. Die sterkste argument ten gunste van privatisering was dat Eskom nie meer oor die menslike hulpbronne en kundigheid beskik het om pro-aktief te krag te voorsien nie. Dit moes eerder die taak van die privaatsektor word. ${ }^{189}$ Eskom het probeer terugkrabbel. Binne die raamwerk van die vryemarkfilosofie, is verklaar, sou meer toegewings gemaak word. Intussen het buitelandse elektrisiteitsmaatskappye planne gemaak om in Suid-Afrika kraginstallasies op die been te bring. ${ }^{190}$ Die respons van plaaslike ondernemings op die krisis was interessant. Terwyl daar inderdaad belangstelling was om krag teen 'n wins te voorsien, het veral groot nywerheidsondernemings intussen strategiese beplanning gedoen om na kragvoorsiening vir hul eie behoeftes om te sien. Teen die einde van April 2008 het Eskom te kenne gegee dat private kragvoorsieners aktief gewerf sou word. Daar het 'n vraag na 4000MW krag (4\% van die land se totale energiebehoeftes) bestaan. ${ }^{191}$ Die tyd sou leer hoe hierdie vraag aangespreek kon word.

184. M le Roux, “Cheaper power lure for foreign investors” in Business Day. 2008.02.06 by http:/ / www.businessday. co.za/articles/dailymailer.aspx?ID=BD4A699789.

185. Ibid.

186. Sapa, "Soybean biofuel plant for Coega?" in IOL, 2008.03.18 by http://www.iol.co.za/index.php?set_ id=1\&click_id=3045\&art_id=nw20080318081201325C751872 (Geraadpleeg 2008.04.28).

187. Anon., "Coega upbeat despite power setback" in Business Day, 2008.04.08 by http://www.businessday. co.za/articles/saexporter.aspx?ID=BD4A743812 (Geraadpleeg 2008.04.28): R van Zyl, "Aluminium smelter still viable investors told, Sowetan, 2008.03.17 by http:/ / www.sowetan.co.za/News/Article.aspx?id=728187 (Geraadpleeg 2008.05.02).

188. In Oktober 2009 is aangekondig dat die projek wat $\$ 2,7$-miljard sou kos, weens Eskom se produksietekorte op die langebaan geskuif is. Kyk T Craemer, “\$2,7bn smelter becomes power-crunch casualty” in Engineering News, 2009.10 .15 by http://www.engineeringnews.co.za/article/27bn-smelter-beomes-power-crunchcasualty-2009-10-15 (Geraadpleeg 2009.12.08).

189. T Cohen, "Monday comment: privatising electricity generation has been a bright idea around the world" in Business Day, 2008.02.18 by http://www.businessday.co.za/articles/bottomline.aspx?ID=BD4A708301

190.S Njobeni, "Solar plant to sell electricity" in Business Day, 2008.04.25 by http://www.businessday.co.za/ articles/article.aspx?ID=BD4A756325 (Geraadpleeg 2008.04.28)

191. T Craemer, "Eskom issues new tender for 2100MW of independent base-load capacity" in Engineering News, 2008.04.30 by http:// www.engineeringnews.co.za/article.php?a_id=132412 (Geraadpleeg 2008.05.09). 


\section{Gevolgtrekking}

Samelewingsontevredenheid met die elektriese kragonderbrekings wat tussen Januarie en April 2008 in Suid-Afrika aan die orde was, kan in baie opsigte beskou word as ' $n$ kapstok wat gebruik was om 'n bepaalde inhoud aan 'n uitsonderlike tyd in die land se geskiedenis te gee. Omstandighede van swak ekonomiese ontwikkeling het die land se mense ongelukkig gestem. Die bril waarmee hulle aan die begin van 2008 na die werklikheid gekyk het, was een wat gekenmerk is deur 'n mentaliteit van swak materiële vooruitsigte. Stygende rentekoerse, duurder brandstof, hoër elektrisiteitstariewe en nou kragonderbrekings, het 'n galbitter mengeldrankie voorberei vir'n gees van ontevredenheid, frustrasie en magteloosheid. Dit is interessant dat die belangrikste motiveringsprekers in die land destyds twee Engelstalige mans was wat 'n groot deel van hulle lewe in koloniale en later onafhanklike Afrikastate deurgebring het. Die een was die skoolhoof van 'n private seunskool ${ }^{192}$ en die ander 'n aartappelboer wat prediker geword het. ${ }^{193}$ Die woorde van hierdie mense het veel daartoe bygedra om deursnee Suid-Afrikaners met 'n meer ruim gemoed na die 'swaarkry van die hede' te laat kyk.

Op die politieke terrein het die krisis rondom kragonderbrekings 'n groter mate van verdeeldheid en oënskynlike wanorde in die hand gewerk. Gewone Suid-Afrikaners het die land se regering regstreeks met Eskom vereenselwig. Daar was 'n duidelike besef dat, ná die Polokwane-konferensie van die ANC, die kabinet van Mbeki nie meer namens die regerende ANC-alliansie gepraat het nie. Die aftakeling van betroubare magstrukture het Eskom as 'n openbare onderneming buitengewoon kwesbaar gemaak.

Dat baie van die kritiek regstreeks voor die deur van Eskom gelê is, was verstaanbaar. Daar was onweerlegbare bewyse van swak bestuur, verkeerde besluite wat geneem is, swak (selfs onbetroubare) finansiële besluitneming en 'n geskiedenis van politiekgemotiveerde bestuursintervensies wat nie in die belang van die land en sy inwoners was nie.

In die ekonomiese milieu is die leemtes vinnig raakgesien. In 'n mededingende sektor waar wins die lewensvatbaarheid van ondernemings bepaal, het sakeleiers min genade gehad vir omstandighede wat, as gevolg van verwaarlosing, hulle winste weggeneem het. 'n Belangrike denkrigting was 'n debat oor die privatisering van kragvoorsiening - ' $n$ tendens wat in die VSA in die vyftigerjare van die twintigste eeu posgevat het, toe die wêreld se voorste kapitalistiese ekonomie ongekende vooruitgang begin maak het. ${ }^{194}$

Dat Suid-Afrikaners, veral in die metropolitaanse sentra van die land, 'n waardevolle les geleer het, ly geen twyfel nie. Hulle het besef dat dit noodsaaklik was om verantwoordelik met elektrisiteit om te gaan. In 2006 toe die Wes-Kaap onder kragonderbrekings mank gegaan het, was mense in die binneland bykans

192. D Knowles, "Is there hope for SA?” in Daily News, 2008.04.09 by http://www.iol.co.za/index.php?set id=1\&click_id=3045\&art_id=vn20080409103318675C482494 (Geraadpleeg 2008.05.20).

193. N Jackson, "40 000 mans bid saam in grootste saamtrek nóg” in Beeld, 2008.04.17 by http://www.news 24. com/Beeld/Suid-Afrika/0,3-975_2307951,00.html (Geraadpleeg 2008.05.20).

194. Kyk as voorbeeld, W Wells, "Public power in the Eisenhower administration" in The Journal of Policy History, 20(2), April 2008, pp. 227-262. 
onbewus van die wesentlike implikasies van kragonderbrekings. Hulle het net sydelings van die WesKapenaars se lotgevalle kennis geneem. ${ }^{195}$ Teen 2008, nadat almal aan voortdurende kragonderbrekings vir meer as drie maande bloot gestel is, was daar aanduidings dat hulle besef het hoe noodsaaklik dit was om verantwoordelik met krag om te gaan. Gemiddelde per capita kraggebruik het reeds teen Februarie 2008 duidelik afgeneem.

Laastens, wil dit voorkom asof mense iets uit die kragonderbrekings geleer het. Daar is kennis geneem van innoverende soeke na oplossings. Ook het 'n gees van omgewingsbewustheid prominent op die voorgrond getree. Die feit dat baie Suid-Afrikaners teen Mei 2008 waarskynlik steeds depressief was oor die vooruitsigte van potensiële verval in die land was nie meer van uitermatige belang nie. Hulle het waarskynlik ander faktore, soos die situasie in Zimbabwe, belangriker gereken as 'n aanduiding van Afrika se agteruitgang. Dit was meer opvallend as die kragkrisis wat reeds bykans vergete was. Dat hulle steeds wantrouig was, ly geen twyfel nie. Die feit dat Eskom teen Meimaand kon voortgaan om krag te lewer, asof daar nog nooit onderbrekings was nie, het mense 'n vraagteken agter die werklike noodsaak vir beurtkrag in die eerste plek laat trek. Opsluit het dit in 2008 gegaan oor politieke dinamika in die menslike milieu van alledaagse kulturele interaksie.

Dit was - met apologie aan George Orwell - duidelik dat die mense van 2008 net in die toekoms kon sien wat in ooreenstemming met hul eie wense vir die toekoms ooreengestem het. Die mees opvallende feite het hulle, net soos ons in 2018, geïgnoreer, omdat dit nie welkom was nie. Dit is net verbasend dat mense destyds (in 2008) so min vir krag betaal het! 